-ISSN: 2148-0494

dergİabant (AİBÜ İlahiyat Fakültesi Dergisi), Bahar 2020, Cilt:8, Sayı:1, 8:121-144

Geliş Tarihi: 17.03.2020

Kabul Tarihi: 04.05.2020

Araştırma Makalesi

Doi: https://doi.org/10.33931/abuifd.705075

\title{
Ayetlerin Mekkîlik ve Medenîliği: Bakara Suresi Son İki Ayeti Örneği
}

\author{
Hamza Sadan*
}

Öz

Sure ve ayetlerin hangi dönemde inmiş olduğunun tespiti son derece önemlidir. Çünkü ayetlerin açlklanmasında Mekkîlik ve Medenîlik önemli faktörlerden biridir. Bu durum vahiydeki tedrici metodun anlaşılmasında ve Kur'an'da neshi kabul edenler için ayetlerden hangisinin önce veya sonra indiğinin tespitinde önemli bir faktördür. Bu nedenle ayetlerin Mekkîlik ve Medenîliği merak edilen konulardan biri olmuştur. Merak konusu hususlardan biri de Bakara suresinin son iki ayetinin Mekkî mi yoksa Medenî mi olduğudur. Çünkü hem Medenî hem de Mekkî olduğuna işaret eden rivayetler bulunmaktadır. Mekkîliğe işaret eden rivayete göre bu ayetler $\mathrm{Hz}$. Peygamber'e Miraç gecesinde hediye olarak verilmiştir. Medenîliğe işaret eden rivayetler ise bu ayetlerin, Medenî olan hemen öncesindeki ayetle ilişkili olduğunu ve bu ayetten sonra geldiğini göstermektedir. Bu konudaki farklı rivayet ve görüşler bir araya getirilerek değerlendirildi ve ilgili ayetlerin Medenîliğine dair görüşlerin daha muteber olduğu sonucuna ulaşldd.

Anahtar Kelimeler: Mekkî, Medenî, Bakara Suresinin Son İki Ayeti, Amenerrasulü, Miraç.

\section{On Determining the Verses as Meccan and Medinan: The Example of the Last Two Verses of the Baqara}

\begin{abstract}
The determination of the period in which suras and verses came down gained importance in the following period. Because Meccan and Medinean have become an important factor in the explanation of the verses. For this reason, the Meccan and Medinean information of the verses have been one of the subjects to be wondered. One of the concerns is whether the last two verses of Surah al-Baqara were Meccan and Medinean. Because rumors indicating that they are both Meccan and Medinean. According to the rumor pointing to Mecca, these verses are given to Muhammad (pbuh) as a gift on the Miraj. The rumors that point to Medinean show that these verses are related to the verse just before the Medinean and came after this verse. In this issue different narrations were gathered and evaluated, and it was concluded that the views on the Medinean of the relevant verses were more reliable.

Keywords: Meccan, Medinean, the Last Two verses of the Surah al-Baqara, al-Baqara 185-186, Miraj.
\end{abstract}

Dr. Öğr. Üyesi, Niğde Ömer Halisdemir Üniversitesi İslami İlimler Fakültesi, Temel İslam Bilimleri Bölümü, Tefsir Anabilim Dalı, hsadan@ohu.edu.tr

ORCID ID 0000-0002-3448-3691 


\section{Giriş}

Mekkîlik ve Medenîlik, Kur'ân'la ilgili bahisleri inceleyen ulûmu'l-Kur'ân'ın (Kur'ân ilimleri) önemli konularından biridir. Dolayısıyla ulûmu'l-Kur'ân yazarları bu konuya büyük önem vermiş ve onu eserlerinde müstakil bölüm içerisinde ele almışlardır. Öte yandan Kur'an'ı açıklama ve yorumlama işini üstlenen müfessirler de kaleme aldıkları tefsirlerinde Mekkîlik ve Medenîliğe kayıtsız kalmamışlardır. Onlar genellikle ayetlerin tefsirine geçmeden önce sureleri kısaca tanıtmaya çalışmışlardır. $\mathrm{Bu}$ bağlamda surenin ayet sayısı, Mekkîliğine ya da Medenîliğine yani nazil olduğu döneme dair bilgiler sunmuşlardır. Eğer içerisinde nüzul dönemi farklı olan ayetler varsa onları da istisna etmek suretiyle aslında bütün ayetleri kapsayacak şekilde surenin kısa bir panoramasını vermişlerdir.

En meşhur tanımına göre, Hz. Muhammed'in Mekke'den Medine'ye hicretinden önce nazil olan ayetlere Mekkî; sonra nazil olanlara ise Medenî denir. ${ }^{1} \mathrm{Bu}$ tanımlama, zamanı (hicreti) esas almaktadır ve buna göre hicretten önce nazil olan ayetler Mekke dişında da nazil olsa Mekkî; hicretten sonra nazil olanlar Medine dışında başka yerlerde nazil olsa da Medenî'dir. Bunun dışında mekân ${ }^{2}$ ve muhatabı ${ }^{3}$ esas alan Mekkî ve Medenîliğin başka tanımları olsa da genel kabul gören yukarıda zikredilen tanım olmuştur. ${ }^{4}$ Dolayısıyla bu çalışmada Mekkîlik ve Medenîliğin hicret temelli bu tanımı esas alınacaktır.

Mekkîlik ve Medenîliğin yukarıda zikredilen meşhur tanımına göre Kur'an ayetleri hicret temelinde ya Mekkî ya da Medenî olarak iki kısımda analiz edilmektedir. Ayetlerin Mekkîlik ve Medenîliğinin tespiti ise genellikle rivayetlere dayanmaktadır. Süyûtî̀nin (öl. 911/1505) naklettiğine göre Kadı Ebû Bekir, el-İntisar isimli eserinde Mekkîlik ve Medenîliği bilme hususunda sahabe ve tabiûnun hafızasına müracaat edileceğini, çünkü bu konuda Hz. Peygamber'in bilgi vermediğini, bunu Allah Teâlâ'nın İslam toplumuna farz kılmadı̆̆ını belirtmektedir. ${ }^{5}$ Bu rivayetten anlaşılacağı üzere rivayetlerin bu konuda önemli bir yeri vardır. Ancak sağlıklı bir sonuca ulaşmak için rivayetlerin sıhhatine dikkat edilmelidir. Nitekim Subhî Salih rivayetlerin doğruluğunun ve güvenilir olma imkânının Mekkî ve Medenî ayetleri belirlemede çok önemli bir ölçü olduğunu belirtmektedir. ${ }^{6}$

1 Ebü’l-Fazl Celâlüddîn Abdurrahmân b. Ebî Bekr es-Süyûtî, el-ítkân fî ulûmi'l- Kur'ân, thk. Mustafa el-Buga (Beyrût: Dâru İbn Kesîr, 1987), 1/37.

2 Mekânı esas alan tanım, Mekke ve çevresinde inen ayetlerin Mekkî; Medine ve çevresinde inenlerin ise Medenî olduğuna işaret etmektedir.

3 Muhatabı esas alan tanım, Mekkelilere hitaben inen ayetlerin Mekkî; Medinelilere hitaben inen ayetlerin Medenî olduğuna işaret etmektedir. Genellikle içerisinde "ya eyyühennas" hitabını içerenler Mekkî; "ya eyyühellezine âmenû" hitabını içerenler Medenî olarak kabul edilmektedir.

4 Tanımlar için bk. Bedrüddîn Muhammed Abdullah ez-Zerkeşî, el-Burhân fî ulûmi'l- Kur'ân, thk. Muhammed Ebu'l-Azl İbrahim (Beyrût: Darü'l-Ma'rife, 1391/1971), 1/187; Süyûtî, el-İtkân, 1/36-37; Muhammed Abdü'l-Azîm ez-Zürkânî, Menâhilü'l-irfân fî ulûmi'l- Kur'ân (Beyrût: Dâru İhyâi Kütübi'l-Arabî, ts.), 1/196.

5 Zerkeşî, Burhân, 1/191; Süyûtî, İtkân, 1/36-37.

6 Subhi b. İbrahim es-Sâlih el-Lübnânî, Mebâhis fî ulûmi'l- Kur'ân (Beyrût: Dâru'l-İlim li'l-Melâyin, 2005), 173. 
Vahyin alıcısı olan Hz. Peygamber risâlet görevini hicretin öncesinde Mekke'de; sonrasında ise Medine'de ifa etmiștir. Hz. Peygamberin peygamberlik görevini iki farklı şehirde yaşadığı süre içerisinde yerine getirmesi ve bu durumun ayetlerin nazil olduğu ortamı iki farklı bölüme ayırmış olması nedeniyle vahyin inzalinin tamamlanmasından sonraki dönemlerde, ayetlerin Mekkî ve Medenîliğinin tespiti ulemanın dikkatini celp etmiştir. Bu süreç hâlâ devam etmektedir. Bunun nedeni ayetlerin Mekkîlik ve Medenîliği ile ilgili rivayetlerin farklılık göstermesi, Mekkî ve Medenîlikle ilgili yeni değerlendirmelerin yapılması ve bazı ayetlerin nüzul ortamıyla ilgili net bilgilerin olmamasıdır.

Bizim bu çalışmamızda Bakara suresinin son iki ayetini seçmemizin sebebi bu ayetlerin Mekkîlik ve Medenîliği ile ilgili birden fazla rivayet ve değerlendirmenin olmasıdır. Kaynaklarda söz konusu ayetler kimi zaman Mekkî kimi zaman da Medenî olarak kaydedilmiştir. Bunun nedeni söz konusu ayetlerin hem Mekkîlik ve Medenîliği hem de sebebi nüzulleriyle ilgili rivayetlerin çeșitlilik arz etmesidir.

Mekkîlik ve Medenîliğin Belirlenmesinde Önemli İki Paradigma: Sebebi Nüzul ve Nesh: Ulūmu'l-Kur'ān yazarları, ayetlerin tarihî bağlamına dair rivayetleri ve bilgileri içermesi açısından nesḩ ve esbâbu'n-nüzûl konularına daha çok ilgi göstermişlerdir. Naklî bir ilim olması açısından Mekkî-Medenî konusu, gelenekte, esbâbu'n-nuzūl ve nesḩ ilimleriyle ilişkilendirilmiştir.

Ayetlerin Mekkîlik ve Medenîliği ile ilgili görüşler verilirken aynı zamanda sebebi nüzullerinin de incelenmesi gerekmektedir. Zira sure ve ayetlerin Mekkîlik ve Medenîliğini belirlemede sebebi nüzullerin önemli bir katkısı vardır. Çünkü sebebi nüzuller genellikle ayetlerin hangi olay veya durumla ilgili olarak inmiş olduğunu gösterir. $\mathrm{Bu}$ olay ve durumun Mekke ya da Medine'de meydana geldiğinin bilinmesinin Mekkî ve Medenî ayetlerin tespitinde önemli bir katkısı vardır.

Âyetlerin çoğu herhangi bir sebebe bağlı olmadan nazil olmuştur. Bunların dışında kalan ayetler ise ya bir hadisenin hükmünü beyan etmek ya da $\mathrm{Hz}$. Peygamber'e sorulan soruları cevaplandırmak üzere nazil olmuştur. ${ }^{7}$ Bu şekilde bir sebebe mebni olarak inmiş olan ayetlerin Mekkîlik ve Medenîliğini tespit etmek için nüzul sebepleri ile ilgili rivayetlerin incelenmesi gerekir. Bu nedenle üzerinde çalıştığımız Bakara suresinin son iki ayeti, sebebi nüzulleri ile birlikte değerlendirilmeye çalışılacaktır.

Nüzul sebepleri ile ilişkisi olan Mekkîlik ve Medenîlik konusu aynı zamanda nesih konusuyla da bağlantılıdır. Çünkü nâsih ve mensûh olan ayetlerin belirlenmesinde Mekkîlik ve Medenîliğin önemli bir katkısı vardır. Nesih, sonra inen ayetin önce inen ayetin hükmünü kaldırmasıdır. Önce inenle sonra inen ayetin belirlenmesinde bu ilmin verilerinden faydalanılmaktadır. Bu nedenle Muhâsibî (öl. 243/ 857), ulûmu'l-Ḳur'ân'a dair yazdığı eserinde, Mekkîlik ve Medenîlik konusunu ayrı bir bölüm altında ele almamış; nesih konusunun içerisinde değerlendirmiştir.

Subhi Sâlih, Mebâhis, 132. 
Muhasibî̀ye göre emir ve hükümlerin tespit edilebilmesi için nesh konusunda dikkate alınması gereken ilk husus Mekkî ve Medenî surelerin bilinmesi gerektiğidir. ${ }^{8}$ Yine Zerkeşî (öl. 794/1392) ve Süyûtî, Mekkîlik ve Medenîliğin bilinmesini Allah Teâlâ'nın ümmete farz kılmadığına ancak nâsih ve mensûhu ayırt etmek için onun bir kısmını ilim ehlinin bilmesi gerektiğine dair bir rivayet nakletmişlerdir. ${ }^{9}$ Dolayısıyla Bakara suresinin son ayetlerinin Mekkîlik ve Medenîliği tartışılırken ayetlerin nâsih- mensûh ilişkisi açısından değerlendirilmesi de gerekmektedir. Zira bu ayetlerin nâsih olduğunu, bir önceki ayeti (284. ayet) neshettiğini söyleyenler ve buna karşı çıkanlar bulunmaktadır.

$\mathrm{Bu}$ açıklamalardan anlaşılmaktadır ki ilgili ayetlerin Mekkîlik ve Medenîliği tartışılırken nüzul sebepleri ve nesih konusuyla iç içe ele alınması gerekmektedir.

\section{Bakara Suresinin Son İki Ayetinin Nüzul Sebepleriyle İlgili Rivayetler}

Bakara suresinin son iki ayeti hakkında gelen nüzul sebepleri ekseriyetle bir önceki ayetle (284. ayet) ilgilidir. Aynı şekilde söz konusu ayetlerin tefsirinde bu vb. rivayetleri müfessirler de paylaşmaktadırlar. ${ }^{10}$ İlgili rivayetler şöyledir:

a- "Allah Resulü'ne "yerde ve göklerdekilerin tamamı Allah'a aittir, siz içinizde bulunanı açık etseniz de gizleseniz de Allah sizi onunla sorgular..."11 ayeti indiğinde bu durum sahabeye çok ağır geldi. Peygamber'e (s.a.v.) geldiler. Sonra diz çöküp: Ya Resulullah! Namaz, oruç, sadaka ve cihad gibi amellerden gücümüzün yettiği hükümler bize teklif edildi. Fakat şimdi de bu ayet sana nazil oldu. $\mathrm{Bu}$ ayetle gelmiş olan hükme gücümüz yetmez. Bu talebin üzerine Hz. Peygamber (s.a.v.): "Acaba iki kitap ehlinin (Yahudiler ve Hristiyanlar) sizden önce "Dinledik, isyan ettik" şeklinde söylediklerini mi söylemek istiyorsunuz. Hayır, böyle söylemeyiniz. "İşittik ve itaat ettik. Ey Rabbimiz! Senden bizi affetmeni isteriz. Nihayetinde dönüş sadece sanadır.

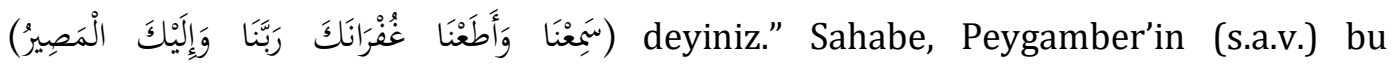
söylediklerini kabul edip onu tekrar ettikleri zaman, Allah Teâlâ bunun arkasından "Peygamber ve inananlar Rablerinden kendisine inzal edilene inandılar. Onların tamamı Allah'a, meleklerine, kitaplarına ve resullerine iman ettiler. Allah'ın resullerinden hiçbirinin arasını ayırmayız. İşittik ve itaat ettik. Ey Rabbimiz! Mağfiretini dileriz. Dönüş yalnız sanadır, dediler"12 ayetini indirdi. Sahabe bu ayeti işittiği zaman Allah Teâlâ ashaba ağır gelen önceki ayeti (...Siz içinizde bulunanı açık etseniz de de gizleseniz de Allah sizi onunla sorgular...) neshetti ve șu ayeti indirdi: "Allah bir kişiye gücü kadar yük yükler. Herkesin kazandı̆̆ı iyiliğin mükâfatı kendisine ve işlediği

8 Hāris el-Muhāsibī, el-Aḳl ve fehmu'l-Ḳur'ân, thk. Huseyn el-Ḳuvvetli (Beyrût: Dāru'l-Fikr, 1971), 394.

9 Zerkeşî, Burhân, 1/191; Süyûtî, Ittkân, 1/38.

10 Bu rivayetlerin mana olarak nakledildiği anlaşılmaktadır. Çünkü aynı konuyla ilgili olarak farklı lafızlarla çok sayıda rivayet geçmektedir. Örneğin bk. Ebû Ca'fer Muhammed b. Cerîr b. Yezîd etTaberî, Câmiu'l-beyân fî te'vîli'l-Kur'ân, thk. Abdullah b. Abdü'l-Muhsin et-Türkî (Dâru Hicr, 2001), $5 / 128-160$

11 el-Bakara $2 / 284$

12 el-Bakara 2/285. 
kötülüğ̈̈n zararı da yine kendisine aittir. Ey Rabbimiz! Unutur ya da kasıtsız olarak hata yaparsak bizi hesaba çekme." Allah Teâlâ buna karşllı olarak "evet" dedi. "Ey Rabbimiz! Bizden evvelkilere yüklediğin gibi bize de ağır yük yükleme” dedikleri zaman "evet" dedi. "Ey Rabbimiz! Güç yetiremeyeceğimiz şeyi bize yükleme" dedikleri zaman "evet" dedi. ${ }^{13}$

b- İbn Abbas'tan nakledilen bir rivayete göre o şöyle demektedir: “...Siz içinizde bulunanı açık etseniz de gizleseniz de Allah sizi onunla hesaba çeker..." ayeti nazil olduğu zaman, sahabenin içine daha önce düşmemiş olan bir korku düştü. Peygamber'in (s.a.v.) onlara "dinledik ve itaat ettik" deyiniz, buyruğu üzerine Allah Teâlâ onların kalbine imanı yerleştirdi ve "Allah bir kişiye gücü kadar yük yükler. Herkesin kazandığı iyiliğin mükâfatı kendisine ve işlediği kötülüğün zararı da yine kendisine aittir. Ey Rabbimiz! Unutur ya da kasıtsız olarak hata yaparsak bizi hesaba çekme." ayetini indirdi. (Müminler bunu tekrar ettikleri zaman) Allah Teâlâ "Bunu size verdim." dedi. "Ey Rabbimiz! Bizden önceki ümmetlere yüklediğin gibi bize ağır yük yükleme" dediklerinde Allah Teâlâ "Bunu da size verdim." dedi. "Ey Rabbimiz! Gücümüzün yetmediği șeyi bize yükleme" dediğinde Allah Teâlâ "Bunu da size verdim." buyurdu. ${ }^{14}$

c- Mücahid'den gelen bir rivayette ise o şöyle demektedir: “İbn Abbas'ın yanına vardım ve ey İbn Abbas! İbn Ömer'le birlikteydim. 0 bir ayet okudu ve ağlamaya başladı, dedim. Hangi ayeti okudu, diye sordu. "...yerde ve göklerdekilerin tamamı Allah'a aittir...” ayetini dedim. Bunun üzerine o: Bu ayet nazil olduğu zaman onun ashabı çok üzüldü ve "ya Resulullah! Allah içimizden geçen şeylerle bizi muaheze ederse, helak oluruz" dediler. Peygamber (s.a.v.) ise "dinledik, itaat ettik deyiniz" dedi onlar da "dinledik ve itaat ettik" dediler. Bu sebeple bu ayet (Bakara 284. ayet) sonraki iki ayetle (Bakara 285. ve286. ayetlerle) neshedildi."15

d- İbn Abbas'tan gelen benzer bir rivayet Bezzar'ın müsnedinde şu şekilde geçmektedir: "...Siz içinizde bulunanı açık etseniz de gizleseniz de Allah sizi onunla sorgular..." ayeti inzal edildiği zaman bu sahabeye ağır geldi ve "hangi birimiz içimizden konuşmayız ki” dediler. Bunun üzerine sonraki iki ayet ( Bakara 285 ve 286. ayetler) indi. ${ }^{16}$

13 Bu rivayet benzer lafızlarla değişik kaynaklarda geçmektedir. Örneğin bk. Ebü’l-Hüseyn Müslim b. el-Haccâc b. Müslim, Muhtasar Sahih-i Müslim, thk. Muhammed Fuad Abdu'l-Bakî (Beyrût: Dâru İhyâi't-Turâsi'l-Arabî, ts.), 1/115; Ebû Abdirrahmân Abdullāh b. Ahmed b. Muhammed b. Hanbel eş-Şeybânî, el-Müsned İmam Ahmed b. Hanbel, thk. Şuayb el-Arnavut, Âdil Mürşid (Müessesetü'rRisâle, 2001), 6/497; Ebû Avâne Ya'kūb b. İshâk, Müstahrec Ebî 'Avâne, thk. Eymen b. Arif (Darü'lMa'rife, 1998), 2/479. Farklı lafızlarla benzer bir rivayet İbn Hibbân'ın Sahihi'nde de geçmektedir: Ebû Hâtim Muhammed b. Hibbân, Șaḥịhu İbn Hibbân, thk. Şuayb el-Arnavut, (Beyrût: Müessesetü'r-Risâle, 1998), 1/350.

14 Bk. Müslim, Muhtasar Sahih-i Müslim, 1/115; Ebû Îsâ Muhammed b. Îsâ et-Tirmizî, Sünenü'tTirmizî (el-Câmi'u'l-kebîr), thk. Beşşar Avvad Ma'ruf (Beyrût: Dârü'l-Garbi'l-İslâmî, 1998)," Tefsîr", 3 (No: 2992 ) ; Ebû Abdirrahmân Ahmed en-Nesâî, es-Sünenü'l-kübrâ, thk. Hasen Abdü'lMün'im (Beyrût: Müessesetü'r-Risâle, 2001), 10/40.

15 Ahmed b. Hanbel, el-Müsned, 5/195.

16 Ebû Bekr Ahmed b. Amr el-Bezzâr, el-Müsnedü'l-Bezzâr, thk. Âdil b. Sa'd (Medine: Mektebetu'lUlûm ve'l-Hikem, 1988), 11/307. 
Yukarıda birbirine benzeyen kimi zaman uzun kimi zaman da kısa olarak geçen rivayetler hemen hemen bütün hadis kaynaklarında bazen aynı bazen de değişik lafızlarla geçmektedir. Ayetlerle ilgili rivayetlerin bu denli yaygın olması ve Bakara suresinin son iki ayetinin konu olarak önceki ayetin mütemmim bir cüzü mahiyetinde olması bu ayetlerin nüzulünün birbiriyle yakından ilişkili olduğu kanısını güçlendirmektedir.

Yukarıda verilen rivayetler Sahih-i Buhârî̀de (öl. 256/870) geçmemektedir. Ancak Buhârî'de 284. ayetin kendinden sonra gelen ayetle neshedildiğine dair bir rivayete yer verilmiştir. ${ }^{17} \mathrm{Bu}$ ayetler arasında nesih ilişkisini ortaya koyan rivayet de yukarıdaki rivayetler gibi hatta daha yaygın olarak hadis kaynaklarında yer almaktadır. ${ }^{18}$

Şu ana kadar zikredilen rivayetler Bakara suresinin son iki ayetinin (285 ve 286. ayet) öncesiyle (284. ayet) ilişkisini ortaya koymaktadır. Bu ilişki bazen önceki ayetle sonraki ayetler arasında nâsih mensuh; bazen de nuzül sebebi olarak teșekkül etmektedir. Her ne şekilde olursa olsun bu rivayetler Bakara suresinin son iki ayetinin Medenî olduğuna dair delil olarak kabul edilmektedir. Çünkü önceki ayetin (284. ayet) Medenîliği hususunda herhangi bir ihtilaf söz konusu değildir. Bu ayet Medenî olduğuna göre ondan sonra gelen ayetin de Medenî olması gerekir. Çünkü önceki ayet sonraki ayetlerin sebebi niteliğindedir. Sebepler sonuçlardan önce meydana gelir. Dolayısıyla bu rivayetleri ve siyak sibak ilişkisini dikkate alanlar Bakara suresinin son iki ayetinin Medenî olduğu düşüncesindedirler.

Esbâbü'n-nüzûl kitaplarında Bakara suresinin son iki ayetinin 284. ayetle ilgili olduğuna ilişkin çok sayıda rivayet verilmiştir. Bu durum yaygın görüşün ayetlerin Medenî olduğuna işaret etmektedir. Ayrıca rivayetlerde bu ayetlerin bir önceki (284. ayet) ayetten bir yıl sonra nazil olduğu da belirtilmektedir. ${ }^{19}$ Rivayetlerde bir yll gibi bir zamanın belirtilmesi ilgili ayetlerin nüzul dönemini biraz daha belirginleştirmektedir.

Bakara suresinin son iki ayetinin Medenî olduğuna işaret eden rivayetleri belirledikten sonra Mekkî olmasına kaynaklık eden rivayetlere geçebiliriz. Bakara suresinin son iki ayetinin Mekkî olduğu görüşünde olanların dayandığı rivayet, bu

17 Ebû Abdillâh Muhammed b. İsmân̂l el-Buhârî, Muhtasaru Sahih-i Buhari, thk. İbrahim Halil Bereket (Beyrût: Dâru'n-Nefais, 1992), 6/33. Ayrıca bk. Ebü'l-Kāsım Süleyman b. Ahmed et-Taberânî, elMu'cemü'l-kebîr, thk. Hamdî bin Abdülmecid Selefî, 2. Baskı (Kahire: Mektebetü İbn Teymiyye, 1994), 9/211. Örneğn bk. Müslim, Muhtasar Sahih-i Müslim, 1/115; Ahmed b. Hanbel, Müsned, 6/497; Ebû Avâne, Müstahrec, 2/479. Ahmed b. Şuayb b. Alî en-Nesâî, es-Sünenüll-kübrâ, thk. Hasen Abdü'l-Mün'im (Beyrût: Müessesetü'r-Risâle, 2001), 10/40.

19 Ebü'l-Hasen Alî b. Ahmed b. Muhammed b. Ali el- Vâhidî, Esbâbü nüzûli'l-Kur'ân, thk. Usâm b. Abdilmuhsin el-Humeydan, 2. Baskı (ed-Demmâm: Dâru'l-Islâh, 1992), 1/96; Ebü'l-Fazl Celâlüddîn Abdurrahmân b. Ebî Bekr es-Süyûtî, Lübâbu'n-nukûl fî esbâbi'n-nüzûl, thk. Ahmed Abdü'ş-Şâfî (Beyrût: Dâru'l Kütübi'l-İlmiyye, ts.), 1/39; Bedrettin Çetiner, Fatiha'dan Nâs'a Esbabı Nüzûl (İstanbul: Çağrı Yayınları, 2013), 1/122. 
ayetlerin Miraç'ta hediye olarak verildiğine dair rivayettir ki şöyledir:

e- Müslim (öl. 261/875) Mürre tarikiyle Abdullah b. Mesud'dan nakletmektedir: “Resulullah İsra'ya gittiği zaman Sidretü'l-Münteha'ya vardı. Sidretü'l-Münteha yedinci semadadır. Yerden yükselen her amel oraya gelir ve oradan alınır. Yukarı taraftan inen ameller oraya gelir ve oradan alınır. Resulullah'a şu üç şey hediye edildi: Beş vakit namaz, Bakara suresinin son iki ayeti ve ümmeti içerisinden Allah'a ortak koşmayanların affedilmesi." ${ }^{20} \mathrm{Bu}$ hadis dikkate alındığında Bakara suresinin son iki ayetinin Mekkî olması zorunlu gibidir. Çünkü söz konusu ayetler rivayete göre Miraç hediyesi olarak verilmiştir. Miraç ise Mekke döneminin sonlarına doğru vaki olmuştur. Bu nedenle Bakara suresinin son iki ayetinin Miraç hediyesi olduğuna dair rivayeti bu șekilde değerlendiren ulema bunları Mekkî olarak kabul etmektedirler.

Bakara suresinin son ayetlerinin öncesiyle ilişkili olduğuna dair zikredilen rivayetlerde olduğu gibi Miraçla ilgili rivayet de Buhârî’de geçmemektedir. Ancak Buhârî dışında birçok hadis kitabında geçmektedir. ${ }^{21}$ Söz konusu ayetlerin hem Mekkî hem de Medenîliğine kaynaklık eden yukarıda zikredilen rivayetler, en sağlam kaynak olarak, Müslim'in Sahihi'nde geçmektedir. Dolayısıyla rivayetler kaynaklık değeri açısından eşit gibidir. Çünkü Müslim'in sıhhat şartlarını taşımaktadır. Ne var ki Bakara suresinin son iki ayetinin Medenîliğine dayanak teşkil eden rivayetler diğerine göre çok çeşitli ve yaygındır. Ayrıca Bakara 284. ayetin 285 ve 286. ayetlerle neshediliğine dair yukarıda zikredilen rivayet Müslim'in Sahihi'yle birlikte hem Buhari'nin Sahihi'nde hem diğer hadis kaynaklarında geçmektedir. Bu, Kur'an'da neshi kabul edenlere göre, ilgili ayetlerin Medenî olduğu hususunda önemli bir dayanaktır.

Konuyla ilgili rivayetleri bu șekilde belirledikten sonra, önce ulûmu'l-Kur'ân sonra da tefsir kaynaklarında Bakara suresinin son iki ayetinin Mekkîlik ve Medenîliğine ilişkin değerlendirmeleri inceleyebiliriz.

\section{Ulûmu'l-Kur'ân Kaynaklarına Göre Bakara Suresinin Son İki Ayetinin Mekkîliği ve Medenîliği Sorunsalı}

Araştırmamızın ikinci ayağını ulûmu'l-Kur'ân kaynakları oluşturmaktadır. Zira bu kaynaklar ayet ve surelerin Mekkî ve Medenîliğine büyük önem atfetmişlerdir.

Zerkeşî (öl. 794/1392),22 Mekkîlik ve Medenîlik konusunu ayrı bir bölümde incelemiş ve bu bölümün başlarında konuyla ilgili olarak Maverdî'nin görüşünü

20 Müslim, Muhtasar Sahih-i Müslim, 1/157.

21 Örneğin bk. Ebû Bekr Abdullāh b. Muhammed b. Ebî Şeybe, Müsned İbn Ebî Şeybe, thk. Âdil b. Yusuf, Ahmed b. Ferid, (Riyad: Dâru'l- Vatan, 1997), 1/197; Ebû Abdillâh Ahmed b. Muhammed b. Hanbel eș-Șeybânî el-Mervezî, el-Müsned İmam Ahmed b. Hanbel, 6/181; Tirmizî, "Tefsîr", 53 ( No: 3276 ); Ebû Abdirrahmân Ahmed b. Şuayb b. Alî en-Nesâî, es-Sünenü'l-kübrâ, thk. Hasen Abdü'l- Mün'im (Beyrût: Müessesetü'r-Risâle, 2001), 7/261.

22 Zerkeşi'den önce de ulûmu'l-Kur'ân'la ilgili eserler kaleme alınmıștır. Ancak ulûmu'l-Kur'ân'a ilişkin ilk sistemli eser Zerkeşî (öl. 794/1392) ile kayda geçmiștir. O, fikıh, hadis gibi diğer alanlarda da eser vermesine rağmen daha çok ulûmu'l-Kur'ân'la ilgili olarak yazdığı "el-Burhân fî 
vermiștir. Buna göre Bakara suresi, bir ayet dıșında bütün âlimlere göre Medenî'dir. İstisna edilen bu ayet ise "23 ayetidir ve Veda haccinda Kurban bayramında Mina'da inmiştir. ${ }^{24}$

Zerkeşî’nin verdiği Maverdî'nin bu görüşüne göre Bakara suresinin bir ayeti dışında Medenîliği âlimler tarafından genel kabul görmüş olduğu belirtilmiş ve bu ayet dışında başka bir ayet istisna edilmemiştir.

Ulûmu'l-Kur'ân'a ilişkin incelediğimiz diğer bir kaynak ise Süyûtî'nin (öl. 911/ 1505) el-ítkân'ıdır. Bu eserde de Mekkîlik ve Medenîlik konusu ayrı bir bölüm içerisinde incelenmiștir ve Zerkeșînnin eserinden daha fazla detaya inilmiștir. Burada Süyûtî Bakara suresinin Medine'de inen ilk sure olduğu bilgisini verdikten sonra, ${ }^{25}$ Mekkî ve Medenî surelerden istisna edilen ayetleri ayrı bir fasıl altında incelemiş ve bu istisnaların neler olduğuna yer vermiştir. 0, Beyhakî’nin (öl. 458/1066) Delailü'nNübüvve isimli kitabında Mekke'de inen surelerin bir kısmının Medine'de tamamlandığına, İbnu'l-Hassâr'ın Mekkî ve Medenî surelerden bazı ayetlerin istisna edildiğine dair görüşlere yer vermiştir. Ayrıca o, İbn-i Hacer'in (öl. 852/ 1449) Buhârî Şerhi'nde şöyle dediğini aktarmıştır: "Ulemadan bazıları Mekkî sûrelerdeki Medenî ayetleri göstermeye önem verirler. Fakat bu durumun tersi de bulunmaktadır. Buna göre surenin bir kısmı Mekke'de inmesine rağmen geri kalan kısmı Medine'de nazil olabilir. (Surenin kendisi Medine'de inebilir). Ancak böyle inen ayetin çok az bulunduğunu gördüm."26

Süyûtî bu bilgileri verdikten sonra kendisine gelen malumatlar ışığında her iki istisna -Mekkî surelerde bulunan Medenî ayetler ve Medenî surelerde bulunan Mekkî ayetler- hakkında elde ettiği bilgileri geniş bir şekilde açılamayı uygun bulduğunu belirtmiş ve sırasıyla surelerden hangi ayetlerin istisna edildiğine değinmiştir. $\mathrm{Bu}$

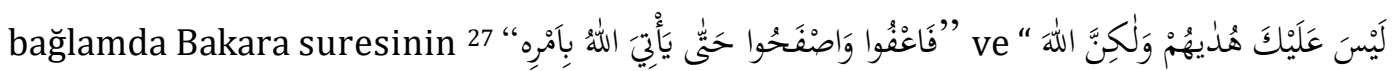
"يَهْهِدي مَنْ يَشَاَكُ 28 ayetlerinin istisna edilmiş olduğunu ifade etmiştir. ${ }^{29}$ Bu iki ayetin nüzul sebepleriyle ilgili rivayetlere bakıldığında bunların Mekke'de indiğine dair bir işaret de bulunmamaktadır. 109. ayet, Süyûtînin Esbâbü'n-Nüzûlünde geçen rivayete göre Allah Tealâ Resulünü Araplardan seçmesinden dolayı Yahudiler içerisinde Araplara en çok kin besleyenlerin Huyey b. Ahtab ve Ebû Yâsir b. Ahtab'ın olması ve inananları İslâm dininden çevirmeye çalışmaları nedeniyle onlar hakkında indirilmiştir. ${ }^{30} \mathrm{Bu}$ durumda ayet Yahudilerle ilgili olarak inmiştir. Kuran'ın Yahudilerle ilişkisi ise genellikle

Ulûmi'l-Kur’ân" isimli kitabıyla meșhur olmuș ve bu eseriyle daha sonra bu konuda yazılacak olan eserlere kaynaklık etmiștir. Bu nedenle konunun ulûmu'l-Kur'ân ayağıyla ilgili araştırmaya bu eserle başlamayı uygun bulduk. el-Bakara $2 / 281$.

Zerkeşî, Burhân, 1/87.

Süyûtî, İtkân, $1 / 43$.

Süyûtî, İtkân, $1 / 56$.

el-Bakara 2/109.

el-Bakara 2/272.

Süyûtî, İtkân, 1/56.

Süyûtî, Lübabü'n-nükûl, 1/15. 
Medine dönemine aittir. Bu nedenle ayetin Mekkî olduğunu gösteren herhangi bir karine bulunmamaktadır. 272. ayet ise Esbâbü'n-Nüzul'de gecen rivayete göre Hz. Peygamberin Müslümanların dışındakilere sadaka verilmemesini emretmesi üzerine; ${ }^{31}$ Süyûtî'nin tefsirinde ise $\mathrm{Hz}$. Peygamber'in müşriklere sadaka vermeyi yasaklaması nedeniyle nazil olduğu belirtilmektedir.32 Diğer kaynaklarda da genellikle müşrik olanlarla ilgili sadakanın yasaklanması geçmektedir. Örneğin bir rivayete göre bir gün Hz. Ebû Bekir'in kızı Esma'ya annesi ve nenesi gelerek kendilerine yardım mahiyetinde bazı şeyler vermesini istemişler, ikisinin de müşrik olması sebebiyle, onlara bir şey vermeyerek: "Resulullah'a sormadan size bir şey veremem. Zira benim dinim üzerinde bulunmuyorsunuz." demesi ve gelip onlara yardım olarak bir şey verip veremeyeceğini Hz. Peygamber'e sorması üzerine Allah Teâlâ'nın bu ayeti indirdiği ifade edilmiştir. ${ }^{33}$ Başka bir rivayette ise İbn Abbas şunları söylediği belirtilmektedir: Ensar'dan bazı kimselerin Kurayza ve Nadîr oğullarından yakınları bulunmaktaydı. Onlara sadaka vermeyi arzu etmiyorlar ve sadaka verebilmeleri için onların Müslüman olmasını istiyorlardı. İşte bunun üzerine "Onları hidayete ulaştırmak sana ait değil. Fakat Allah kime dilerse hidayeti ona verir." ayeti nazil oldu. ${ }^{34}$

Süyûtî’nin, Bakara suresinden istisna edildiğine ilişkin yukarıda verdiği iki ayetle ilgili rivayetler görüldüğü gibi çeşitlilik arz etmektedir. Bu nedenle söz konusu ayetlerin Mekkî olduğuna dair net bir bilgi bulunmamaktadır. Kaldı ki bu ayetlerin Mekkî olduğuyla ilgili görüşler çok yaygın değildir.

Asıl konumuz bu ayetlerin (109 ve 272) Mekkîlik ve Medenîliği değildir. Bu ayetlerin üzerinde durmamızın sebebi Bakara suresinin son iki ayetinin Mekkî olması durumunda istisna edilen bu ayetlerin içerisinde zikredilmesi gerekliliğindendir. Yukarıdaki bilgiler ışığında Mekkî surelerde Medenî ve Medenî surelerde Mekkî ayetlerin olduğu ortadadır. Ancak ayetlerin Mekkîlik ve Medenîliğini tespit konusu önem arz etmektedir. Mekkî ayetlerde Medenî; Medenî ayetlerde Mekkî ayetlerin tespiti konusu âlimler tarafından rivayetler dikkate alınarak belirlenmeye çalışılmıştır. Rivayetler ise -Bakara suresinin sonu ile ilgili rivayetlerde olduğu gibifarklılıklar arz etmektedir. Yukarıda görüldügü üzere Bakara suresinin istisna edilen 109 ve 272. ayetleriyle ilgili rivayetler çeşitlenmektedir. Bu durum ayetlerin siyak ve sibak bütünlüğü dikkate alınarak rivayetlerin değerlendirilmesini ve bu șekilde bir sonuca ulaşmanın daha doğru olabileceği düşüncesini güçlendirmektedir. Bu da ictihadi bir özellik arz etmektedir. Nitekim Mekkî ve Medenî surelerden istisna edilen ayetlerin ictihadi olduğuna itimat eden bazı müfessirler olduğ ${ }^{35}$ bildirilmektedir. ${ }^{36}$

Süyûtî, Lübabü'n-nükûl, 1/38.

Celâleddin el-Mahallî - Celâleddin es-Süyûtî, Tefsîrü'l-Celâleyn (Kâhire: Dâru'l- Hadis, ts.), 45.

Râzî, Mefâtîhu'l-gayb, 7/76.

Taberî, Câmiu'l-beyân, 2/63.

Süyûtî bu durumu, istisna edilen ayetlerin hikmetinin ictihaden olduğunu belirterek görüşleri uzlaştırmaya çalışmaktadır.

36 Suyuti, İtkân, 1/23. Ayrıca bk. Subhî Salih, Mebâhis, 179. 
Süyûtî, Mekkî ve Medenî surelerden istisna edilenler bölümünde Medenî Bakara suresinden sadece yukarıdaki iki ayetin istisna edildiğine ilişkin rivayetleri vermesine rağmen aynı eserin başka bir bölümünde (yerde ve gökte inen ayetler başlığı altında) ise şöyle bir rivayete yer vermiştir: “İbn Arabî şunları söylemektedir: Hibetullah'tan gelen rivayete göre altı ayet dışında Kur'ân'ın hepsi Mekke ile Medine arasında inmiştir. Ayetlerden altısı ise ne yeryüzünde ne de semada inmiştir ${ }^{37}$. Bunlar Saffât suresinde üç ayet (Bizim her birimizin belirli bir yeri var... ayetiyle birlikte üç ayet), ${ }^{38}$ Zuhruf suresinde bir ayet (Senden önce gönderdiğimiz resullerimizden sor... $)^{39}$ ve Miraç gecesinde inmiş olan Bakara suresinin sonundaki iki ayettir. ${ }^{40} \mathrm{Bu}$ rivayete göre Bakara suresinin Miraç gecesinde hediye edilen son iki ayetinin Mekkî olması ve Bakara suresinden istisna edilen ayetler arasında yer alması gerekirdi. Oysa istisna edilen ayetler içerisinde yer verilmemiştir.

Ayrıca Süyûtî, yukarıdaki rivayetle ilgili şunu söylemektedir: "Şunu söylemek isterim ki, Bakara suresinin son iki ayeti hariç, diğerlerinin ne yerde ne de gökte indiği, hakkında herhangi bir delile rastlayamadım". Bakara suresinin son iki ayetiyle ilgili delil olarak verdiği hadiste ise Resûlüllah'a Miraç’ta üç şeyin verildiği bahsedilmektedir. Bunlardan ilki beş vakit namaz, ikincisi Bakara suresinin “âmenerresulü” diye bilinen son ayetleri, üçüncüsü ise Resûlullah'ın ümmeti içerisinden Allah'a şirk koşmayanların affedileceğidir. ${ }^{41}$

Yine Süyûtî'nin naklettiği bașka bir rivayette ise Bakara suresinin son iki ayetinin "kābe kavseyn" durumunda nazil olduğu ifade edilmektedir.42 "Kābe kavseyn" durumunda indiğini belirten bu rivayete dayanılarak Bakara suresinin sonunun İsra ve Miraç gecesinde inmiş olduğu düşünülmektedir. Ancak "kābe kavseyn"e dair görüşler birbirinden farklıdır.

"Kābe kavseyn" Necm suresinin 9. ayetinde geçmektedir ve iki yay ucu kadar yaklaşmak, iki arşın kadar mesafe kalması veya yay ile kirişi arasındaki kadar mesafe $^{43}$ gibi anlamlara gelmektedir. Bütün bu anlamlardan hangisi dikkate alınırsa alınsın ayet, iki zatın birbirine iyice yaklaştıkları anlamını taşımaktadır.

Birbirine yaklaşan zevatın kimler olduğuna ilişkin farklı görüşler vardır: Bunlardan birinci görüş Hz. Peygamber ile Miraç'ta Allah Teâlâ'nın,44 ikincisi Hz. Peygamber ile Cebrail'in (a) üçüncüsü ise Cebrail ile Allah Teâlâ'nın ${ }^{45}$ birbirine

\footnotetext{
İbn Arabî bu rivayette Hibetullah'ın "ne yeryüzünde ne de semada" sözüyle, yer ve gök arasındaki uzayı kastetmiș olabileceğini bildirmektedir bk. Süyûtî, İtkân, 1/ 90. es-Sâffât 37/164-166.

ez-Zuhruf $43 / 45$.

Süyûtî, İtkân, 1/ 90.

Süyûtî, İtkân, 1/90.

Süyûtî, İtkân, 1/90.

Taberî, Câmiu'l-beyân, 22/18.

Ferra, Meani'l-Kur'ân, 3/ 95.

Taberî, Câmiu'l-beyân, 12/16-20.
} 
yaklaştığına dairdir. Ancak en yaygın ve makbul olan Hz. Peygamberle Cebrail'in (a) birbirine yaklaştığına ilişkin görüştür.

İlgili rivayetlere bakıldığında, görüldüğü gibi, "kābe kavseyn"in birbirine çok yakınlaşmak anlamında ittifak olmasına rağmen bu yakınlaşmanın kimler arasında olduğu noktasında ihtilaf bulunmaktadır. Diğer bir ihtilaf noktası ise yakınlaşmanın nerede olduğuna dairdir. İlgili rivayetlere bakıldığında Hz. Aişe bu ayet hakkında Hz. Peygamber'in ilk karşılaşmasında Cebrail'i kendi suretinde Ecyad denilen yerde gördüğünü bildirmektedir.46 Ulûmu'l-Kur'ân yazarlarından biri olan Subhî Salih (1926-1986) ise Bakara suresinin son iki ayetinin İsra ve Miraç gecesinde inmesini başka bir rivayetin sıhhatli olmasına bağlamıştır: 0, "Zuhruf suresinde geçen "Senden önce göndermiş olduğumuz resullerimize sor: Rahmân'ın dışında kulluk edilebilecek başka tanrılar yapmış mıyız?"47 ayetinin İsra'da Beyti Makdis'te indiği sahih ise İbn Arabi'nin de söylediği gibi Miraç saatlerinde Allah'ın büyük ayetlerini gördügü zaman inmiştir." 48 Buna göre ilgili ayetlerin Miraç gecesinde inmiş olması bir şarta bağlanmıştır. $\mathrm{Bu}$ da rivayetlerin sıhhatli olmasıyla alakalıdır.

Bakara suresinin son iki ayetinin "kābe kavseyn" durumunda indiğini belirten ilk rivayete göre ise bunların İsra ve Miraç gecesinde inmiş olduğu anlatılmak istenmektedir. "kābe kavseyn"le ilgili bu iki rivayet birbirinden çok uzak iki farklı zaman dilimini göstermektedir: Bakara suresinin son iki ayetinin İsra ve Miraç gecesinde nazil olduğunu belirten rivayet -İsra ve Miraç hadisesi Mekke döneminin sonlarına doğru vuku bulmuş olması nedeniyle- Mekke döneminin sonunu; Hz. Aișe'den gelen Peygamber'in Cebrail'i ilk kez Ecyad'da gördüğüne dair rivayet ise Mekke döneminin başını işaret etmektedir. $\mathrm{Bu}$ da iki rivayet arasında, Mekke döneminin başı ve sonu gibi büyük bir zaman farkının olmasını intaç etmektedir.

Necm suresinin Mekke döneminin ilk zamanlarında nazil olduğu dikkate alınırsa "kābe kavseyn"nin Ecyad denilen yerde gerçekleşmiş olması ihtimal dâhilindedir. Nitekim Kurtubî (öl. 671/1273) kābe kavseyn ayetininin hemen öncesindeki "0 yüksek ufukta idi." 49 buyruğunda geçen "yüksek ufuk" ifadesi ile İsra gecesinin kastedildiğini ancak bunun zayıf bir görüş olduğunu söylemektedir. ${ }^{50}$

Ulûmu'l-Kur'ân kaynaklarında geçen yukarıda zikredilen rivayetler şu şekilde değerlendirilebilir:

1- “Kābe kavseyn"le ilgili rivayetler ve müfessirlerin açılamaları incelendiğinde "kābe kavseyn"in Miraç'ta gerçekleștiğine dair net bir bilgi elde edilememektedir. Çünkü "kābe kavseyn” in hem Miraç’ta olduğuna hem de vahyin ilk zamanlarında olduğuna dair rivayet ve görüşler bulunmaktadır. Ayrıca yukarıda da bahsedildiği gibi "kābe kavseyn"in kimler arasında olduğuna dair rivayetler de

Taberî, Câmiu'l-beyân, 12/17-18.

ez-Zuhruf 43/45.

Subhi Sâlih, Mebâhis, 173.

en-Necm 53/7.

Ebû Abdillâh Muhammed b. Ahmed el-Kurtubî, el-Câmi li ahkâmi'l-Kurur'ân, thk. Ahmed el-Berdûnî, İbrahim Atfeș (Kahire: Dâru'l-Kütübi'l-Mısrıyye, 1964), 20/15. 
birbirinden çok farklılık arz etmektedir. Dolayısıyla "kābe kavseyn"in Miraç'ta vaki olduğu hakkındaki görüş kesinlik arz etmemektedir.

2- Zerkeşî̀nin “Bakara suresi, bir ayet dışında bütün âlimlere göre Medenî’dir.

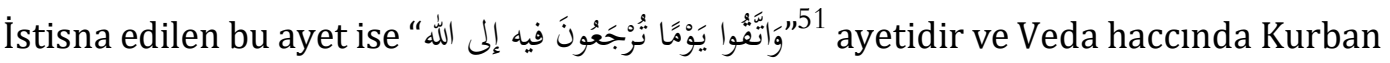
bayramında Mina'da inmiştir" şeklindeki rivayet ise Mekkîlik ve Medenîliğin muteber tanımını değil "mekân" odaklı tanımını esas almıștır. Muteber tanım "hicret" odaklıdır ve nüzulü hicretten önce olanlar Mekkî, sonra olanlar ise Medenî’dir. Bu durumda

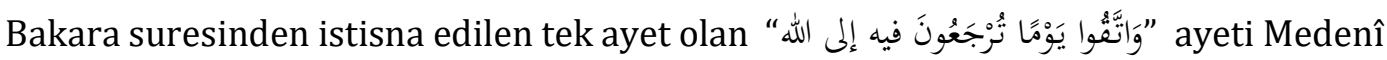
olmaktadır. Böylece Bakara suresinin tamamı Medenî'dir diyebiliriz.

3- Bakara suresinin son iki ayetinin hem Miraç'ta hediye edildiğine hem de "kābe kavseyn" durumunda verildiğine dair rivayetleri Süyûtî ilgili yerlerde aktarmasına rağmen bunları Bakara suresinden istisna etmemiștir ve bu ayetlerin bizzat Mekkî olduğuna dair bir rivayet ve bir görüş de ileri sürmemiştir. Bu durumda o, ayetlerin Miraç'ta hediye edildiğine ve "kābe kavseyn" durumunda verildiğine ilişkin rivayetleri vermekle birlikte ilgili ayetleri Medenî olarak görmektedir.

4- Yukarıda zikredilen, Bakara suresinin son iki ayetinin miraç hediyesi olduğuna dair rivayeti sahih olarak kabul edersek -ki Müslim, sıhhat şartlarına uygun olduğu için eserine almıştır- bu rivayet, söz konusu ayetlerin bir önceki ayetle alakalı olarak nazil olduğunu belirten ve dolayısıyla onların Medenîliğine işaret eden rivayetlerle çelişmektedir. Bu çelişkiyi ortadan kaldırmaya yönelik Ahmed b. Hanbel'in Müsnedi'nin haşiyesinde Sindî (öl. 1138/1726) şöyle bir açıklama yapmaktadır: "Muhtemelen bu ayetlerin (Bakara suresinin son iki ayetinin) Hz. Peygamber'e Miraç'ta verileceği takdir edilmiş ve bu ayetler sana indirilecektir, denilmiştir. Bu yüzden Bakara suresinin son iki ayetinin (285 ve 286. ayet) önceki ayetle (284. ayet) bağlantılı olarak nazil olduğuna ilişkin rivayetlerle Miraç hediyesi olduğuna dair rivayetler birbiriyle çelişmemektedir."52 Sindî'nin bu değerlendirmesine göre Bakara'nın son iki ayeti Miraç'ta hediye olarak verilmiş olması ilerde bu ayetlerin Hz. Peygamber'e inzalinin müjdesinin verilmesi anlamını taşımaktadır. Bu şekilde söz konusu ayetlerin önceki ayetle bağlantılı olarak indiğine dair rivayetlerle Miraç hediyesi olduğuna dair rivayet uzlaştırılmıştır. Sindî bu değerlendirmesinde Bakara suresinin son iki ayetinin Medenî olduğuna işaret eden rivayetleri esas alarak miraçta hediye edildiğine dair rivayeti yorumlayarak uzlaştırmaya çalışmıştır. Sindî’nin bu açıklamasını dikkate alacak olursak Miraç'la ilgili hadis sahih olmakla birlikte Bakara suresinin son iki ayeti Medenî’dir diyebiliriz.

el-Bakara 2/281.

Ebü'l-Hasen Nûruddîn Muhammed b. Abdilhâdî es-Sindî, Haşiyetü's- Sindî alâ Müsnedi'l-İmâm Ahmed b. Hanbel, thk. Ebu Muaz Tarık (Riyad: Dâru'l- Me'sur li'n-Neşr ve't-Tevzi', 1431/2010), 1/619. Ayrıca bk. Ahmed b. Hanbel, Müsned, 6/182. sayfanın dipnotu. 


\section{Bakara Suresinin Son İki Ayeti ile Bir Önceki Ayet Arasında Nesih İlişkisi Olduğuna Dair Görüşlerin Değerlendirilmesi}

Bakara suresinin son iki ayetiyle ilgili dikkat çeken diğer bir husus hemen

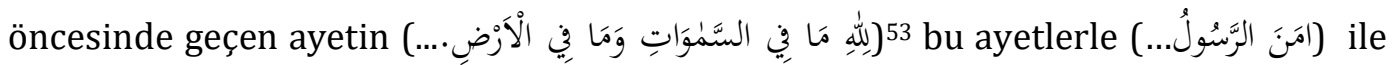
neshedildiğine $\mathrm{e}^{54}$ dair bilgilerdir.

Bakara suresinin son ayetleri arasında nesih ilișkisinin olduğuna dair rivayetin hem Buhârî'de hem de diğer birçok hadis kaynağında geçtiği ifade edilmişti. Bu rivayetlerden mütevellit birçok müfessir ve ulûmu'l-Kur'ân müellifleri söz konusu ayetler arasında nesih ilişkisinden bahsetmektedir. Ancak konuyu Süyûtî'nin İtkân'ı üzerinden değerlendirmek daha doğru olacaktır. Zira o, nesih konusunu genel olarak almıștır. Bu yüzden başka bazı detayları orada görme imkânı bulacağız. Ayrıca bu ayetler arasında nesih ilişkisinin olduğunu söyleyenler benzer açıklamalarda bulunmaktadırlar.

Süyûtî, Ittkân'da, âlimlerin nesih konusunda tilaveti baki hükmü mensûh çok sayıda ayetin olduğunu kabul ettiklerini ancak bunların sayısının fazla olmadığını ifade etmektedir. ${ }^{55}$ Bunun yanında az sayıdaki nâsih ve mensûh ayetler içerisinde bu ayetleri de zikretmiştir. ${ }^{56}$ Dolayısıyla nâsih ve mensûhun sayısının az olduğu kabul edilmesine rağmen söz konusu ayetler arasında nesih ilişkisinin olduğunun belirtilmesi bu görüşün ne kadar yaygın olduğunu ortaya koymaktadır. Ancak bazı âlimler neshin sadece ahkâmda olabileceği ahbarda olamayacağı kuralından hareketle bu ayetler arsında nesih vaki olmayacağını ifade etmektedirler.

Burada bizi ilgilendiren bu ayetler arasında nesih ilişkisini kimlerin kabul edip etmediği değildir. Önemli olan husus ayetler arasında nesih vaki olduğunu kabul etmemiz durumunda ayetlerin Mekkî ve Medenîliği ile ilgili bir hususu göz önünde bulundurmamız gerektiğidir. 0 da şudur: Nesheden ayetle neshedilen ayet arasında öncelik ve sonralık ilişkisinin olmasıdır. Bu durumda Bakara suresinin son iki ayetinin nâsih (nesheden) olarak bir önceki mensûh (neshedilen) ayetten sonra nazil olması gerekmektedir $\mathrm{Bu}$ çerçevede İslâm uleması, âyetler arasında neshin olup olamayacağının tespiti noktasında iki âyetten ilk inen âyetin hangisi olduğunun kesin olarak bilinmesi, neshe konu olan hükmün iyilik, maruf ve ahlaki kuralları içermemesi, haber içerikli olmaması gibi bazı şartlar ortaya koymuşlardır. ${ }^{57} \mathrm{Bu}$ durum Bakara suresinin son iki ayetinin "Miraç’ta inmiştir dolayısıyla Mekkîdir" diyenlerin görüşüne ters düşmektedir. Çünkü mensûh olan ayet (284. ayet) Medenîdir ve Medenîliği hususunda bir ihtilaf söz konusu değildir. Bu ayet Medenî ise

el-Bakara 2/284

Menna Kattan, Mebâhis, 1/251.

Suyuti, Itkân, 3/71.

Suyuti, İtkân, 3/73.

Arslan Karaoglan, "Mâturîdîye Göre Nesih Problematiği", Kahramanmaraş Sütçü İmam Üniversitesi İlahiyat Fakültesi Dergisi 34 (31 Aralık 2019), 73-111. 
nesheden Bakara suresinin son iki ayeti de (285 ve 286. ayet) Medenî olmak durumundadır.

Kural olarak nâsih mensûhtan sonra gelmelidir. Ancak bazı ayetler için bu kural esnetilmiş ve istisna olarak bazen nâsih önce de gelebilir denilmiştir. Dolayısıyla nâsihin mensûha tekaddüm ettiği ayetler tartışılmıştır. ${ }^{58}$ Örneğin Süyûtî bu şekilde olan ayetlerin sayısını dört tane olduğunu beyan etmiştir. ${ }^{59}$ Fakat o, Bakara suresinin son iki ayetini bu dört ayet içerisinde vermemiştir. Bu durumda onun, ya bu ayetleri Medenî olarak değerlendirmiş ya da rivayetleri analiz etmeden ilgili yerlerde vermiş olduğu sonucu ortaya çıkmaktadır.

İlgili ayetler arasında nesih ilişkisi olduğuna dair rivayetler Buhârî’nin ve Müslim'in Sahihi'yle birlikte hemen hemen bütün hadis kaynaklarında geçmektedir. Buna ilaveten birçok müfessir de bu rivayeti paylaşmaktadır. Eğer iddia edildiği gibi Bakara suresinin son ayeti bir önceki ayeti neshediyorsa bu durumda onun medenî olması gerekir.

\section{Tefsirlerde Bakara Suresinin Son İki Ayetinin Mekkî ve Medenîliği Sorunsalı}

Hem Esbâbü'n-nüzûl hem de ulûmu'l-Kur'ân kaynaklarında Bakara suresinin son iki ayetinin bir önceki ayetle ilgili olarak sahabenin Hz. Peygamber'e serzenişte bulunması sonucunda inzal edildiği, önceki ayetin bu ayetlerle neshedildiğine dair görüşleri ve rivayetleri zikrettik. Söz konusu ayetlerle ilgili zikredilen bu hususlar aynı şekilde tefsir kaynaklarında mevcuttur. Dolayısıyla burada tefsir kaynaklarının çok ayrıntıya girmeksizin genel hatlarıyla değerlendirilmesi, müfessirlerin yaklaşımına vakıf olmak açısından, kâfidir.

Tefsirlerde geçen ayetle ilgili açıklamalar yani metin içi yorumlar sonra da Bakara suresinin başında verilen Mekkîlik ve Medenîlikle ilgili bilgiler değerlendirilecektir. Bakara suresinin son iki ayeti hemen öncesindeki ayetle ilişkilendirildiği için bununla ilgili yorumları kısaca özetlemekte fayda vardır.

1- Önceki ayette geçen "İçinizdekini açık etseniz de, gizleseniz de Allah sizi, onunla sorgular.” ayeti önceki ayette geçen şahitliği gizlemekle ilgilidir. ${ }^{60}$ Buna göre ayet Bakara suresinin sonuyla ilgili değil de öncesiyle ilgilidir. Çünkü şahitliği gizleyip gizlememek insanın iradesindedir ve insanlar bu durumdan sorumludur. Şahitliği gizleyen hakkın, doğrunun ve adaletin ortaya çıkmasına mani olmaktadır. Şahitliği gizlememenin, doğru şahitlik yapmanın önemi başka ayetler de de ifade edilmiştir. Dolayısıyla şahitliğin gizlenmesinden dolayı insanlar sorguya çekileceklerdir. $\mathrm{Bu}$ görüşe göre 284. ayetin hükmü daima geçerlidir veya neshedilmemiştir.

Zerkeşi, Burhan, 2 /38; Suyuti, İtkân, 3/78.

Suyuti, Ittkân, 3/78.

Taberî, Câmiu'l-beyân, 5/128. 
2- Sadece önceki ayette geçen şahitlikle ilgili değildir. Ayetin hükmü geneldir. Bu şekilde düşünenler ayetin hükmünün mensûh olduğunu kabul edenler ve mensûh olduğunu kabul etmeyenler olarak iki grupta değerlendirilebilir.

a- Ayetin hükmü geneldir ve ayet muhkemdir. Mensûh da değildir. Bu görüşte olanlar şu iki rivayet bağlamında ayeti açıklamaktadırlar:

Birincisi, "Bu hususta Abdullah b. Abbas'ın "İçinizde olanı açık etseniz de gizleseniz de Allah sizi, onunla sorgular." ayetini açıklarken şunları dediği rivayet edilmiştir: "Bu ayet mensuh değildir. Fakat aziz ve yüce olan Allah, kıyamet günü mahlûkatı bir araya topladığı zaman onlara şunu söyleyecektir: "Şüphesiz ben meleklerimin vakıf olmadıkları içinizde sakladığınız şeyler hakkında size haber veriyorum. Müminlere haber verip nefislerinden geçirip sakladıkları şeyleri bildirdikten sonra affedecektir. "Allah, sizi onunla hesaba çekecek ve dilediğini bağışlayacaktır." ayetinin anlamı budur. Yani, nefsinizde sakladığınızı size bildirecektir, demektedir. Şek ve şüphe içinde olanlara gelince Allah, nefislerinde sakladıkları yalanlamalarını onlara bildirecektir. Dolayısıyla "o, dilediğini bağışlar dilediğine ise azap eder." sözünün anlamı budur. Aynı şekilde Allah Teâlâ'nın: "Allah sizi, kalplerinizin kazandığı şeyler sebebiyle hesaba çeker." sözü inancında şek ve nifak içinde olanlar hakkındadır." 61 Bu rivayete göre kullar hem fiilen işledikleri amellerden hem de yapmadıkları ancak yapmak istedikleri düşüncelerinden dolayı da sorumludur. Sorguya çekilecektir.

İkincisi, bu düşüncede olanların bir kısmı ise şu rivayeti kullanmaktadır: “Dahhâk'ın Hz. Aişe'den rivayetine göre bu ayet neshedilmemişti. Fakat bu ayet, sadece şahitlik yapanlarla alakalı olmayıp bütün insanları kapsamaktadır. Allah Teâlâ, bu ayetiyle insanları, işledikleri gizli ve açı tüm yaptıklarından sorgulayacağını ve yaptıkları veya yapmayı düşündükleri gizli ve aşikâr tüm işledikleri ameller sebebiyle onları hesaba çekeceğini açlklamıştır. Fakat yapmak istedikleri gizli işlerinin karşılığını dünyada sıkıntı ve meşakkate sebep olan felaketler ve belalar şeklinde verir. Bu konuda, Dahhâk, Hz. Aişe'nin şunu dediğini nakletmektedir: "Kim, bir fenalık yapmayı düşünür de onu fiili olarak yapmazsa Allah ona, yapmak istediği fenalık kadar meşakkat ve elem verir. Bu meşakkat ve elemler onun bu fenalığı yapmak istemesinin kefaretidir. Zeyd, Ümeyye'nin Hz. Aişe'den "İçinizde olanı açık etseniz de gizleseniz de Allah onunla sizi sorguya çeker." ayet-i kerimesiyle "Kim bir fenalık yaparsa onun karşılığını görecektir."62 ayetinin manasını sorduğu zaman, Hz. Aişe'nin cevaben şöyle dediğini nakletmiştir: "Ben Resulullah'a bu iki ayeti sorduktan sonra kimse benden onların anlamlarını sormamıştı. Resulullah şöyle söylemişti: "Ey Aişe! $\mathrm{Bu}$ ayetler Allah'ın, kullarını izlediğine işaret etmektedir. Öyle ki, kuluna sıtma ya da farklı bir musibet verir. Ya da ona bir dikenin batmasını hatta evindeki bir şeyi kaybolmasını diler. Bu vesileyle kulunun üzülmesini sağlar. Sonra da kaybolan şeyi

Taberî, Camiu'l-beyân, 5/139.

Taberî, Camiu'l-beyân, 5/142-143. 
koltuğunun altında (kendi üzerinde) bulmasını sağlar, öyle ki mü'min, kırmızı altının körükten çıktığı gibi günahlarından çıkar (kurtulur)."63

b- Ayet sadece şahitlikle ilgili değildir ve ayetin hükmü geneldir. Ancak sonraki ayetler bu ayeti neshetmiştir. Bu görüşte olanlara göre ayet kulların hem fiili olarak yaptıklarından hem de bizzat yapmadıkları ama yapmayı düşündüklerinden hesaba çekileceğini bildirmek için nazil olmuştur. Bu nedenle sahabeye ayet ağır gelmiş ve serzenişte bulunmuşlardır. Bunun üzerine son iki ayet nazil olmuş ve Bakara suresinin 284. ayetini neshetmiştir. İște bu görüşte olanlar Bakara suresinin son iki ayetinin önceki ayetlerle ilişkili olarak nazil olduğunu düşünmektedirler. Dolayısıyla ayetlerin nüzul sebeplerine dair verdiğimiz rivayetler bu grup tarafından dikkate alınmış ve bunları açıklamalarında kullanmışlardır. Bu rivayetler oldukça fazladır. Bununla ilgili olarak Taberî çok sayıda rivayeti zikretmektedir ve bunlar tefsir kaynaklarının çoğunda da geçmektedir. ${ }^{64}$

Görüldüğü üzere müfessirler Bakara suresinin 284. ayetini tefsir ederken açıça belirtsinler veya belirtmesinler- bazıları sonraki ayetlerle neshedildiğine bazıları ise neshedilmediğine ilişkin görüşü dikkate almışlardır. Müfessirlerin ayetle ilgili nesih temelinde yaklaşımları bu şekildedir. Bakara suresinin son iki ayetinin tefsirinde ise dikkat çeken aşağıdaki hususlar bulunmaktadır:

Semerkandî (öl. 373/983) bazı âlimlerin bu ayet dışında Kur'an'ın tamamının Hz. Muhammed'e Cebrail vasıtasıyla indirildiğini, bu ayetin ise Miraç gecesinde hediye edildiğini; buna mukabil bazılarının ise bu ayetlerin Miraç'ta inmediğini, çünkü Miraç gecesinin Mekke döneminde vaki olduğunu ve Bakara suresinin tamamının Medine döneminde nazil olduğunu iddia ettiklerini bildirmekte ve bu görüşleri şöyle değerlendirmektedir: Miraç gecesinde hediye edildi diyenlere gelince onlar şunu söylemektedirler: Hz. Peygamber yanında Cebrail olduğu halde yüksek bir mevkiye semanın üstüne ulaştı. Ta ki sidretül müntehaya vardılar. Cebrail "ben buradan ileriye geçemem senden başka kimse buradan ileriye geçmekle emrolunmadı" dedi. Hz. Peygamber orayı geçip Allah Teâlâ'nın dilediği yere gelince Cebrail Rabbini selamlaması için işaret etti. Bunun üzerine o "et-tehıyyâtü lillâhi ve'ssalevâtü ve't-tayyibât" dedi. Bunun üzerine Allah Teâlâ: "es-selâmü aleyke eyyuhe'nnebiyyü ve rahmetullâhi ve berakâtüh" buyurdu. Bu kez Hz. Peygamber ümmetinin de bu selamdan nasiplenmesini isteyerek : "es-selâmü aleynâ ve alâ ıbadil-lahi's-sâlihîn" diye duada bulundu. Cebrail de gökteki meleklerle birlikte: "eşhedü ellâ ilahe illallah ve eșhedü enne muhammeden abduhü ve resûlüh" sözüyle şehadette bulundular. Allah

63 Taberî, Camiu'l-beyân, 5/142-143.

64 Örneğin bk. Taberî, Camiu'l-beyân, 5/130-138; Ebü'l-Hasen Mukatil b. Süleymân b. Beşîr, Tefsîru Mukatil, thk. Ahmet Ferit (Beyrût: Dâru'l Kütübi'l-İlmiyye, 2002), 1/153; Ebû Bekr Abdürrezzâk b. Hemmâm b. Nâfi' es-San'ânî, Tefsîrü'l-Kur'ân, thk. Mustafa Müslim Muhammed (Riyad: Mektebetü'r-Rüsş, 1989), 1/111; Hûd b. Muhakkem el-Huvvârî, Tefsîru'l-Kur'ni'l-aziz (Beyrût: Dâru'l-Garbi'l-İslamî, 1990), 1/263-264. Bu maddeyle ilgili baktığımız tefsir kaynaklarından bazılarını (ilk dört tanesini) burada gösterdik. Diğer birçok tefsir kaynağı aynı şekilde bu rivayetlere yer vermiştir. 


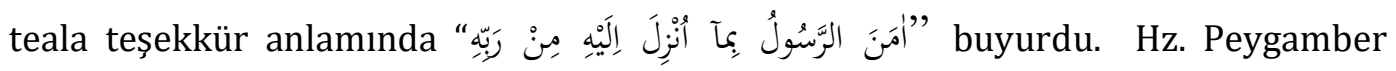

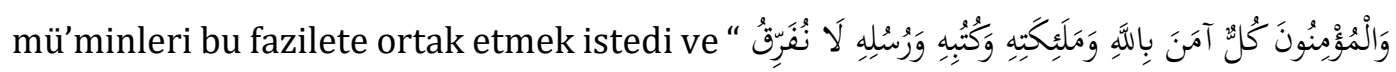

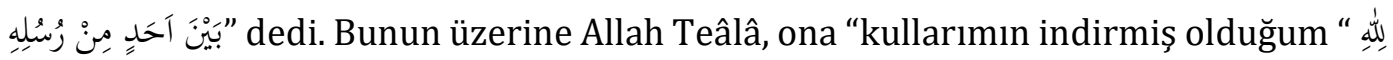

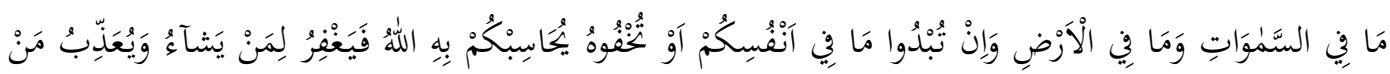

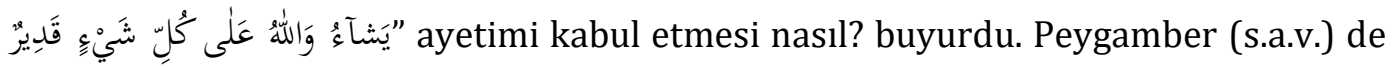

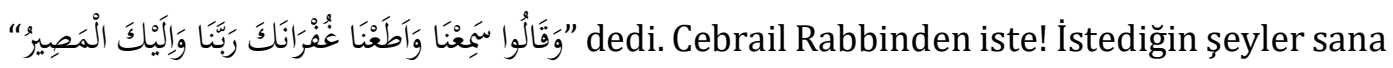
verilecektir dedi. Bunun üzerine Peygamber (s.a.v.) sonraki ayette geçen duaları söyleyerek rabbinden isteklerde bulundu. ${ }^{65}$ Semerkandî'nin zikrettiği yukarıdaki rivayete göre Bakara suresinin son iki ayetinin verilmesi tahiyyat duasıyla benzerlik göstermektedir. Her ikisi de Allah Teâlâ ile Hz. Peygamber arasında karşıllklı konuşmadan müteşekkildir. Ancak rivayetin bizi ilgilendiren kısmı bakara suresinin 284. ayetinin de rivayet içerisinde geçmesidir. Rivayete göre Hz. Peygamber, Miraç'ta Bakara suresinin son iki ayetini sem'an (dinleyerek) alırken, 284. ayet kastedilerek, kullarımın ayetimi kabulü nasıl şeklinde bir soru yöneltilmiştir. 284. Ayet medenidir ve Mekkî olduğuna dair hiçbir rivayet bulunmamaktadır. Daha sonradan Medine'de inecek olan bir ayet Miraç’ta zikredilmiştir. Bu durumda bu kısmın rivayete sonradan dâhil edilmiş olabileceği düşüncesine neden olmaktadır. Zira ayetin diğer sebebi nüzulleri çok yaygın olduğu halde yukarıdaki rivayet çok nadir olarak geçmektedir.

Ebû Hayyân (öl. 373/983) ise Bakara suresinin son iki ayetinin nüzul sebebinin bir önceki ayet olduğunu açıkladıktan sonra Mervezi'den, ibn Abbas, İbn Sirin, Mücahid ve Hasen'in bu iki ayeti Cebrail'in indirmediğini, Hz. Peygamber'in Miraç'ta vasıtasız olarak işittiğini ve Bakara suresinin bu iki ayet dışında Medenî olduğunu söylediklerine dair bir rivayeti paylaşmaktadır. ${ }^{66} \mathrm{Bu}$ rivayete göre Bakara'nın son iki ayetinin Mekkî olduğu açıkça belirtilmiştir. Genellikle söz konusu ayetlerin Miraç'ta verildiğine dair rivayetler zikredilmekte ancak burada ifade edildiği gibi Mekkî olduğu belirtilmemektedir. Bu rivayetin aksine Çağdaş müfessirlerden Şinkîtî (1974) ise bir açıklamasında “" لأَتُوَاخِذْنَا إنِ نَِّينَا ayetinin Medenî olduğunu açıkça belirtmiştir. 67 Yine Derveze, Bakara suresinin son iki ayetiyle önceki ayet arasındaki bağlantının fark edilecek kadar belirgin olduğunu söylemektedir. ${ }^{68}$ Aynı şekilde o, Medine'de nazil olan ayetlerin birçoğunda bu tür vaad ve müjdelerin

Ebü'l-Leys Nasr b. Muhammed b. Ahmed es-Semerkandî, Bahru'l-ulûm (Beyrût: Dâru'l-Kütübi'lİlmiyye, 1993), 1/240-241. Benzer bir değerlendirmeyi Kurtubî de yapmaktadır. Ancak o bu ayetin sebebi nüzulünün bir önceki ayet (284. ayet) olduğuna dair diğer rivayetleri de zikretmektedir bk. Kurtubî, el-Câmi li ahkâmi'l-Kur'ân, 4/ 491-493.

66 Ebû Hayyân Muhammed b. Yûsuf b. Ali, el-Bahrü'l-muhîț, thk. Âdil Ahmed Abdulmevcûd, Alî Muhammed Muavvad (Kâhire: Dâru'l-Kitabü'l-İslami, 1992), 2/378.

67 Muhammed el-Emîn b. Muhammed eș-Șinkītî, Edvâül'-beyan fî îzahi'l-Kur'ân bi'l-Kur'ân (Beyrût: Darü'l-Fikir, 1995), 1/188.

68 Muhammed İzzet Derveze, et-Tefsîru'l-hadîs, trc. Ekrem Demir (İstanbul: Ekin Yayınları, 1998), 5/323-324. 
olduğunu ve bu iki ayetle Allah Teâlâ'nın Müslümanlara sürekli bir müjdelemeyi öngördügünü belirtmektedir." 69 Bakara suresinin 285. ve 286. ayetlerinin içeriğinin Mekkîlik veya Medenîlik açısından çok fazla değerlendirmenin olmadığını göz önünde bulundurursak Derveze'nin yukarıdaki verilen açıklamalarının çok önemli olduğunu söyleyebiliriz.

Müfesssirlerin metin içi açıklamalarında Bakara suresinin Mekkî ve Medenîliği ile ilgili çok fazla öznel değerlendirmelerin olmadığını, genellikle söz konusu ayetlerle ilgili rivayetleri aktardıkları ancak kendilerine göre hangi görüşün doğru olduğuna dair bir değerlendirme yapmadıkları görülmektedir.

Metin içi bilgilerin yanında konuya ışık tutabilecek diğer bir husus da müfessirlerin sure başlarında Mekkîlik/Medenîlikle ve surelerden istisna edilen ayetlerle ilgili verdikleri bilgilerdir. Dolayısıyla Bakara suresinin başında Mekkî ve Medenî olduğuna ve istisna edilen ayetlerin neler olduğuna dair müfessirlerin açılamalarının değerlendirilmesi de konuyu netleştirmek açısından önem arz etmektedir.

Bakara suresinin başında sureyle ilgili olarak müfessirlerin vermiş oldukları bilgilere göre surenin Mekkîlik ve Medenîliğe ilişkin üç farklı açıklamada bulundukları görülmektedir. Onlar bazen kendi görüşleri olarak bazen rivayetleri aktarmak bazen de hem kendi görüşlerini hem de rivayetleri vermek suretiyle bu açıklamaları yapmaktadırlar. Buna göre:

a- Bakara Suresinin tamamı istisnasız olarak Medenîdir. Bu görüşte olanlar, Huvvârî (öl. 300/913), ${ }^{70}$ İbn Ebî Zemenîn (öl. 399/1008), ${ }^{71}$ İbn Kesîr (öl. 774/1373),72 Âlûsî (öl. 1270/1854), ${ }^{73}$ Kâsımî (öl. 1332/1914), ${ }^{74}$ Reşit Rıza (öl. 1354 /1935) ${ }^{75}$ gibi müfessirlerdir. Bu müfessirler özellikle "tamamı" kaydını koyarak Bakara suresinin medeni olduğunu belirtmişlerdir.

b- Bakara suresi Medenîdir. Bu görüşte olanlar surenin tamamının Medenî olduğunu belirtmeksizin ve herhangi bir ayet istisna etmeksizin sadece "Medenî" olduğunu ifade etmişlerdir. Mukâtil (öl. 150/767),76 Semerkandî (öl. 373/983),,77

Muhammed Hüseyin Fadlullah, min Vahyi'l Kur'ân (İstanbul: Akademi Yayınları, 1990), 5/123127.

Huvvârî, Tefsîru'l-Kur'ni'l-Aziz, 1/77.

71 Ebu Abdillah Muhammed b. Abdillah b. İsa İbn Ebi Zemenîn, Tefsîru'l-Kur'âni'l-azîz (Kahire: Dâru'l Fârûki'l-Hadise, 1423), 1/120. Ebü'l-Fidâ' İmâdüddîn İsmâîl b. Şihâbiddîn Ömer b. Kesîr b. Dav' b. Kesîr, Tefsîru'l-Kur'âni'l-azîm, thk. Sami b. Muhammed Selame (Dâru Tayyibe, 1999), 1/149. Şehâbeddin Mahmûd el-Âlûsî, Rûhu'l-meânî fí tefsîri'l-Kur'âni'l-azîm ve's-sebi'l-mesânî, thk. Ali Abdü'l-Bârî Atıyye (Beyrût: Dâru'l-Kütübi'l-İlmiyye, 1415/1995), 1/101.

74 Muhammed Cemâlüddîn b. Muhammed Saîd b. Kāsım el- Kâsımî, Mehasinü't-te'vil, thk. Muhammed Basıl (Beyrût: Darü'l-Kütübü'l-İlmiyye, 1418), 1/241.

75 Muhammed Reşîd Rızâ, Tefsîru'l-Menar (Tefsîru'l-Kur'âni'l-hakim) (el-Heyetü'l-Mısriyyetü'lAmme, 1990), 1/103.

76 Mukatil b. Süleymân, Tefsîru Mukatil, 1/28.

77 Semerkandî, Bahru'l-Ulûm, 1/85. 
Sa'lebî (öl. 427/1035), ${ }^{78}$ Mekkî (öl. 437/1045),79 Begavî (öl. 516/1122), ${ }^{80}$ Zemahşerî (öl. 538/114), ${ }^{81}$ İbn Atıyye (öl. 541/1147), ${ }^{82}$ İbnü’l-Feres (öl. 595/1199), 83 Nesefî (öl. 710/1310), ,84 Seâlebî (öl. 427/1035), ${ }^{85}$ İbn Âdil (öl. 880/1475),86 Îcî (öl. 905/1500), ${ }^{87}$ Şirbînî (öl. 977/1570), ${ }^{88}$ Ebu's-Suûd (öl. 982/1477), ${ }^{89}$ İbn Acîbe (öl. 1224/1809), 90 Şevkanî (öl. 1250/1834), ${ }^{91}$ Seyyid Kutub (öl. 1387/1966),92 ibn Așur (öl.

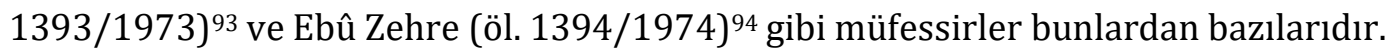
Şevkanî ${ }^{95}$ ve İbn Âdil ${ }^{96}$ gibi bazı müfessirler de 281. ayetin istisna edilmesini zayıf bir görüş olarak vermişlerdir. İbn Atıyye de 281. ayetin son inen ayet olduğuna dair rivayeti vermiştir.97

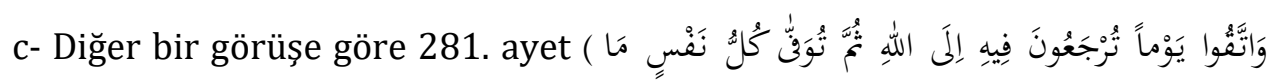
dişında Bakara suresi Medenîdir. Bu ayet ise Mekkîdir. Çünkü Veda

78 Ebû İshâk Ahmed b. Muhammed b. İbrâhîm es-Sa'lebî, el-Keşf ve'l-beyân an tefsîri'l-Ķưr'ân, thk. İbn Aşûr, (Beyrût: Dâru İhyâi't-Türasi'l-Arabî, 2002), 1/135.

79 Ebû Muhammed Mekkî b. Ebî Tâlib Hammûş b. Muhammed, Tefsîru'l-hidâye ilâ bulûği'n-nihâye, (b.y.: Câmiu'ş-Şerîka, 2008), 1/117. Ebû Muhammed el-Hüseyn b. Mes'ûd el-Begavî, Mealimü't-tenzil fi tefsîrul Kur'ân, thk. Abdürrezzak el-Mehdi (Beyrût: Darü İhyâi't-Türasi'l-Arabiyyi, ts.), 1/58. Ebü'l-Kâsım Mahmûd b. Ömer ez-Zemahşerî, el-Keșşâf an hakâikı ğavâmizi't-tenzîl (Beyrût: Dâru'l-Kitabi'l-Arabî, 1407/1987), 1/19. Ebû Muhammed Abdullāh İbn Atıye, el-Muharreru'l-veciz fí tefsîri'l-kitabi'l-aziz, thk. Abdü'sSelam Abdü'ş-Şafi Muhammed (Beyrût: Darü’l-Kütübi'l-İlmiyye, 1422/2001), 1/81. Ebû Muhammed İbnü'l-Feres, Ahkamü'l-Kur'ân, thk. Dr. Taha b. Ali (Beyrût: Darü'bnü'l-Hazm, 2006), 1/37.

84 Ebü'l-Berekât Hâfizüddîn Abdullah b. Ahmed en-Nesefî, Medârikü't-tenzîl ve hakāaiku't-te’vîl, thk. Yusuf Ali Bedîvî (Beyrût: Dâru'l-Kelimi't-Tayyib, 1998), 1/35. Ebu Abdirrahman b. Muhammed es-Seâlebî, el-Cevâhiri'l-hisân fî tefsîri'l-Kur'ân, thk. Muhammed Ali Muavvid (Beyrût: Dâru İhyâi't-Türasi'l-Arabî, 1997), 1/174. Ebû Hafs Sirâcüddîn Ömer b. Nûriddîn Alî b. Âdil, el-Lübâb fi 'ulûmi'l-kitâb, thk. Âdil Ahmed Abdü'l-Mevcûd vd. (Beyrût: Dâru Kütübi'l-İlmiyye, 1998), 1/250. Muhammed b. Abdirrahmân b. Muhammed el-Î́cî, Camiu'l-beyan fi tefsîru'l-Kuran, thk. Abdü'lHamid Hindavî (Beyrût: Dâru'l Kütübi'l-İlmiyye, 2004), 1/25. Şemsüddîn Muhammed b. Ahmed el-Hatîb eş-Şirbînî, es-Sirâcü'l-münîr fi'l-iâne alâ marifeti ba ‘̇̀̇ meânî kelâmi Rabbine'l-Hakîmi'l-Habîr (Kâhire: Matbaatu Bulak, 1285/1868), 1/14. Ebu's-Suûd el- İmadî Muhammed b. Muhammed Mustafa, İrșâdüll-akli's-selîm ilâ mezâya'l-kitâbi'lkerîm (Beyrût: Dâru İhyâi Kütübi'l-Arabî, ts.), 1/20. Ebü'l-Abbâs Ahmed b. Muhammed b. Mehdî eş-Şâzelî, el-Bahrü̈'l-medîd fî tefsîri'l-Kurrânni'l-mecîd, thk. Ahmed Abdullah el-Kureşî (Kâhire: Doktor Hasan Abbas Zeki, 1419/1998), 1/71. Ebû Abdillâh Muhammed b. Alî b. Muhammed eș-Șevkânî es-San'ânî, Fethu'l-kadîr (Beyrût: Dâru İbn Kesîr, 1414/1994), 1/32.

92 Seyyid b. Kutub b. İbrâhîm b. Hüseyn, fî Zıllâli'l-Ḳur’ân (Beyrût: Dâru’ş-Şurûk, h. 1412/1992), $1 / 36$.

93 Muhammed et-Tâhir b. Muhammed b. Muhammed et-Tâhir b. Așur, et-Tahrir ve't-tenvir (Tunus: Dâru't-Tunisiyye, 1984), 1/201. Muhammed b. Ahmed b. Mustafâ Ebû Zehre, Zehretü't-tefâsîr (Kâhire: Dâru'l-Fikri'l- Arabi, ts.), $1 / 91$.

95 Şevkânî, Fethu'l-Kadîr, 1/32.

96 İbn Âdil, Lübâb, 1/250.

97 İbn Atıye, Muharreru'l-Veciz, 1/81. 
haccında nazil olmuştur. Maverdî (öl. 450/1058),98 İbnül Cevzî (öl. 597/1201), ${ }^{99}$ Râzî (öl. 606/1210), ${ }^{100}$ İzz b. Abdisselam (öl. 660/1262), ${ }^{101}$ Kurtubî (öl. 671/1273),, ${ }^{102}$ ibn Cüzey (öl. 741/1341), ${ }^{103}$ Hâzin (öl. 741/1341), ${ }^{104}$ Nisaburî (öl. 850/1446), 105 Süyûtî (öl. 911/1505),106 Merağî (öl. 838/1435) ${ }^{107}$ gibi müfessirler bu görüştedirler.

Bakara suresinin nazil olduğu döneme ilişkin gruplandırılarak yukarıda verilen müfessirlerin görüşlerine göre "a" ve " $b$ " grubunda yer alan müfessirler Bakara suresinin Medenî olduğunu bildirmektedirler. Bunlardan "a" grubundakiler bizzat "tamamı" şeklinde bir kayıt koyarken "b" grubundakiler sadece "Medenîdir" demekle yetinmişlerdir. " $c$ " grubunda yer alan müfessirler ise Bakara suresinin Medenî olduğunu kabul etmekle birlikte 281. ayetin Mekkî olduğunu söylemişler ya da Mekkî olduğuna dair rivayeti benimsemişlerdir. Onlara göre ayetin Mekkî olmasının delili ise Veda haccında Mekke'de nazil olmasına ilişkin verilen rivayetlerdir. Ayetin Veda haccında Mekke'de nazil olmasını, Mekkîliğine delil kabul edilmesi tamamen Mekkîlik ve Medenîliğin tanımıyla ilgilidir. Mekkîlik ve Medenîliğin tanımı mekân temelli olarak alınırsa Bakara 281. ayetinin Mekkî kabul edilmesi isabetlidir. Ancak Mekkî ve Medenîliğin yaygın ve neşhur tanımı daha önceden ifade edildiği gibi hicret odaklı olandır. Buna göre hicretten önce nazil olan Mekke dışında başka bir yerde de nazil olsa Mekkî; hicretten sonra Medine dişında başka bir yerde de nazil olsa Medenîdir. Mekkî ve Medenîliğin bu genel tanımına göre Medenî Bakara suresinden istisna edilen 281. ayeti Mekkî değil Medenî olmaktadır. Çünkü hicretten sonra nazil olmuştur. Mekke'de inmiş olması sonucu değiştirmez. Bu durum da Bakara suresinin tamamı Medenî olmaktadır. Nitekim Ebû Zehre de buna yakın bir değerlendirmede bulunmuştur. ${ }^{108}$

\section{Sonuç}

"Amene'r-rasûlü" diye başlayan Bakara suresinin son iki âyetinin biri Mekkî diğeri Medenî olduğuna ilişkin iki farklı yaklaşım bulunmaktadır. Her iki yaklaşımın temelinde farklı rivayetler bulunmaktadır. Bu ayetlerin Mekkîliğine işaret eden

Ebü'l-Hasen Alî b. Muhammed b. Habîb el-Basrî el-Mâverdî, en-Nüketü ve'l-uyûn (Beyrût: Dâru Kütübi'l-İlmiyye, ts.), 1/63.

Ebü'l-Ferec Cemâlüddîn Abdurrahmân b. Alî b. Muhammed el-Cevzî, Zadü'l-mesîr fî İlmi't-Tefsîr (Beyrût: Dâru'l-Kitabi'l-Arabî, 1422/2001), 1/24.

Ebû Abdillâh Fahrüddîn Muhammed b. Ömer b. Hüseyn er-Râzî, Mefâtîhu'l-gayb (Beyrût: Dâru İhyâi't-Türasi'l-Arabî, 1420/1999), 2/249.

İzzuddîn Abdulaziz b. Abdusselâm b. Ebi'l-Kâsım b. Hasan es-Sülemî, Tefsîrü'l-Kur'âni'l-Azîm, thk. Dr. Abdullah b. İbrahim, (Beyrut: Daru İbn Hazm, 1996), 1/93.

Kurtubî, el-Câmi li Ahkâmi'l-Kur'ân, 1/237.

Ebü'l-Kâsım Muhammed b. Ahmed b. Muhammed b. Abdillah İbn Cüzey, et-Teshîl li ulûmi't-tenzîl (Beyrût: Dâru Kütübi'l-İlmiyye, 1995), 1/49.

Ebü'l-Hasen Alâüddîn Alî b. Muhammed b. İbrâhîm el-Hâzin, Lübâbü't-te’vîl fî me âni't-tenzîl, thk. Abdi's-Selam Muhammed Şahin (Beyrût: Dâru Kütübi'l-İlmiyye, 2004), 1/19.

Nizâmüddîn Hasen b. Muhammed b. Hüseyn el-A'rec en-Nîsâbûrî, Ġarâ'ibü'l-Kur'ân ve reg் a’’ibü'lfurkān (Beyrût: Dâru Kütübi'l-İlmiyye, 1996), 1/128.

Süyûtî, ed-Dürru'l-mensûr (Beyrût, ts.), 1/46.

Ahmed b. Mustafa el-Merâgî, Tefsîru'l-Merâgî (Şerike Mektebe: Matbaatu Mustafa el-Bâbi'lHalebî, 1946), 1/39.

Ebû Zehre, Zehretü't-tefâsîr, 1/75. 
rivayetlerde Hz. Muhammed'e Miraç'ta hediye olarak verildiği; Medeniliğine işaret eden rivayetlerde ise bunların önceki ayetle (284. ayet) bağlantılı olarak nazil olduğu ifade edilmektedir.

Söz konusu ayetlerin Mekkî ve Medenî olduğuna işaret eden bu rivayetler birçok kaynakta geçmektedir. Bunların içerisinde en güvenilir olanı Müslim'in Sahihi'dir. Bu nedenle kaynaklık açısından her iki rivayet birbirine eşittir. Ancak Bakara suresinin son iki ayetinin Medenî olduğuna işaret eden rivayet diğerine göre hem çok yaygın olarak hem de birden fazla değişik lafızlarla geçmektedir.

İlgili ayetlerin Mekkîlik ve Medenîliği ile ilgili bu rivayetlere dayanan görüşler hem ulûmu'l-Kur'ân hem de tefsir kitaplarında bulunmaktadır. Ancak bu kaynaklarda konu tutarlı bir şekilde ele alınmamıştır. Çünkü bazı ulûmu'l-Kur'ân eserlerinde bir yerde Mekkî olduğu belirtilirken başka yerde bu dikkatten kaçmıştır. Aynı şekilde bazı tefsir kitaplarında Bakara'nın başında bu ayetleri istisna etmeksizin surenin Medenî olduğu ifade edilirken söz konusu ayetlerin tefsirinde Mekkî olduğuna dair değerlendirmeler bulunmaktadır. Bu durum belki konuyla ilgili net bir şey söylemenin zor olmasından kaynaklanmaktadır. Zira konuya kaynaklık eden rivayetler sıhhatlidir. Rivayetler sahih olduğu için bu rivayetler ilgili ayetlerin Medenîliği temelinde uzlaştırılmaya çalışılmıştır. Bu bağlamda Bakara'nın son iki ayetinin Miraç hediyesi olduğuna ilişkin rivayet, bu ayetlerin Hz. Peygamber'e ilerde indirileceğinin takdir edildiği şeklinde açıklanmıştır.

$\mathrm{Bu}$ ayetlerin Medenî olduğuna dair değerlendirmeler diğerine göre oldukça yaygın ve muteberdir. Bunu Bakara'nın başında, sureyle ilgili verilen bilgilerde net bir şekilde görmekteyiz. Çünkü -inceleyebildiğimiz- bütün tefsirlerde Bakara suresinden 281. ayet istisna edilirken "Amene'r-rasûlü" diye başlayan son iki ayet istisna edilmemiştir. 281. ayetin ise istisna edilmesi Veda haccında Mina'da nazil olmasından dolayıdır. Ancak 281. Ayetin Veda haccında Mina'da nazil olması hicret temelli tanıma göre ayetin Medenî olmasına engel değildir. Bu durumda Bakara suresi istisnasız Medenî olmaktadır.

Sonuç olarak Bakara suresinin son iki ayetinin Medenî olarak değerlendirilmesi hem buna dair rivayetlerin yaygınlığı hem bu ayetlerin öncesiyle anlam bakımından ilişkili olması hem de müfessirlerin ve ulemanın genel kanaatinin bu yönde olması nedeniyle daha isabetlidir. 


\section{Kaynakça}

Ahmed b. Hanbel, Ebû Abdillah b. Muhammed eş-Şeybânî. el-Müsned İmam Ahmed b. Hanbel. thk. Şuayb el-Arnavût, Âdil Mürşid. Müessesetü'r-Risâle, 1. Basım, 2001.

Âlûsî, Şehâbeddin Mahmûd. Rûhu'l-meânî fî tefsîri'l-Kur'âni'l-azîm ve's-sebi'l-mesânî. thk. Ali Abdü'l-Bârî Atıyye. Beyrût: Dâru'l-Kütübi'l-İlmiyye, 1. Basım, 1415/1995.

Begavî, Ebû Muhammed el-Hüseyn b. Mes'ûd b. Muhammed. Mealimü't-tenzil fi tefsîri'l-Kur'an. thk. Abdürrezzak el-Mehdî. Beyrût: Darü İhyâi't-Türâsi'l-Arabiyyi, ts.

Bezzâr, Ebû Bekr Ahmed b. Amr. el-Müsnedü'l-Bezzâr. thk. Âdil b. Sa'd. Medine: Mektebetu'lUlûm ve'l-Hikem, 1988.

Buhârî, Ebû Abdillâh Muhammed b. İsmâîl. Muhtasaru sahihi Buhari. thk. İbrahim Halil Bereket. Beyrût: Dâru'n-Nefais, 5. Basım, 1992.

Çetiner, Bedrettin. Fatiha'dan Nâs'a esbab-ı nüzûl. İstanbul: Çağrı Yayınları, 2013.

Derveze, Muhammed İzzet. et-Tefsiru'l-hadîs. trc. Ekrem Demir. İstanbul: Ekin yayınları, 1998.

Ebû Hayyân, Muhammed b. Yûsuf. el-Bahrü̈l-muhîț. thk. Âdil Ahmed Abdu'l-Mevcûd, Alî Muhammed Muavvad. Kâhire: Dâru'l-Kitabü'l-İslami, 2. Basım, 1992.

Ebü'l-Leys es-Semerkandî, Nasr b. Muhammed b. Ahmed. Bahru'l-ulûm. Beyrût: Dâru'lKütübi'l-İlmiyye, 1993.

Ebu's-Suûd, el- İmadî Muhammed b. Muhammed Mustafa. İrşâdü'l-akli's-selîm ilâ mezâya'lkitâbi'l-kerîm. Beyrût: Dâru İhyâi Kütübi'l-Arabî, ts.

Ebû Zehre, Muhammed b. Ahmed b. Mustafâ. Zehretü't-tefâsîr. Kâhire: Dâru'l-Fikri'l- Arabi, ts. Fadlullah, Muhammed Hüseyin. min Vahyi'l-Kur'ân. İstanbul: Akademi Yayınları, 1990.

Hatîb eș-Şirbînî, Şemsüddîn Muhammed. es-Sirâcü'l-münîr fi'l-iâne alâ marifeti ba'żı meânî kelâmı Rabbine'l-hakîmi'l-habîr. Matbaatu Bulak, 1285/1868.

Hâzin, Ebü'l-Hasen Alâüddîn Alî b. Muhammed. Lübâbü't-te’vîl fî me âni't-tenzîl. thk. Abdi'sSelam Muhammed Şahin. Beyrût: Dâru Kütübi'l-İlmiyye, 1. Basım, 2004.

Huvvârî, Hûd b. Muhakkem. Tefsiru'l-Kur'ni'l-aziz. Beyrût: Dâru'l-Garbi'l-İslamî, 1. Basım, 1990.

İbn Abdusselâm, İzzuddîn Abdulaziz b. Ebi'l-Kâsım. Tefsîrü'l-Ķur'âni'l-azîm. thk. Dr. Abdullah b. İbrahim. Beyrût: Dâru İbn Hazm, 1. Basım, 1996.

İbn Âdil, Ebû Hafs Sirâcüddîn Ömer b. Nûriddîn Alî. el-Lübâb fì 'ulûmi'l-kitâb. thk. Âdil Ahmed Abdü'l-Mevcûd vd. Beyrût: Dâru Kütübi'l-İlmiyye, 1998.

İbn Așûr, Muhammed et-Tâhir b. Muhammed b. Muhammed et-Tâhir. et-Tahrîr ve't-tenvîr. Tunus: Dâru't-Tunisiyye, 1984.

İbn Atıyye, Ebû Muhammed Abdullāh. el-Muharreru'l-veciz fí tefsîri'l-kitabi'l-aziz. thk. Abdü'sSelam Abdü'ş-Şafi Muhammed. Beyrût: Darü'l-Kütübi'l-İlmiyye, 1. Basım, 1422/2001.

İbn Cüzey, Ebü'l-Kâsım Muhammed b. Ahmed b. Muhammed. et-Teshîl li ulûmi't-enzîl. Beyrût: Dâru Kütübi'l-İlmiyye, 1. Basım, 1995.

İbn Ebî Şeybe, Ebû Bekr Abdullāh b. Muhammed. Müsned İbn Ebî Şeybe. thk. Âdil b. Yusuf, Ahmed b. Ferid. Riyad: Dâru'l- Vatan, 1. Basım, 1997.

İbn Ebî Zemenîn, Ebû Abdillah Muhammed b. Abdillah b. İsa. Tefsîru'l-Kur'âni'l-azîz. Kahire: Dâru'l Fârûki'l-Hadise, 1423/2002.

İbn Hibbân, Ebû Hâtim Muhammed. Șahịḥu İbn Hibbân. thk. Şuayb el-Arnavut. Beyrût: Müessesetü'r-Risâle, 1. Basım, 1998.

Ebû Avâne, Ya'kūb b. İbrâhîm. Müstahrec Ebî 'Avâne. thk. Eymen b. Arif ed- Dimeșkî. Darü'lMa'rife, 1. Basım, 1998. 
İbn Kesîr, Ebü'l-Fidâ' İmâdüddîn İsmâîl b. Şihâbiddîn Ömer b. Kesîr b. Dav' el-Kaysî el-Kureşî el-Busrâvî ed-Dımaşkī eş-Şâfiî. Tefsîru'l-Kur'ani'l-azim. thk. Sami b. Muhammed Selame. Dâru Tayyibe, 2. Basım, 1999.

İbnü'l-Cevzî, Ebü'l-Ferec Cemâlüddîn Abdurrahmân b. Alî b. Muhammed. Zadü'l-mesîr fî ilmi'ttefsîr. Beyrût: Dâru'l-Kitabi'l-Arabî, 1. Basım, 1422/2001.

İbnü'l-Feres, Ebû Muhammed. Ahkâmü'l-Kur'ân. thk. Dr. Tâha b. Ali. Beyrût: Darü İbnü’l-Hazm, 1. Basım, 2006.

Îcî, Muhammed b. Abdirrahmân b. Muhammed. Câmiu'l-beyân fi tefsîri'l-Kuran. thk. Abdü'lHamid Hindavî. Beyrût: Dâru'l-Kütübi'l-İlmiyye, 1. Basım, 2004.

İzzuddîn b. Abdusselâm, Abdulaziz b. Ebi'l-Kâsım b. Hasan es-Sülemî. Tefsîrü'l-Ķur'âni'l-Azîm. thk. Dr. Abdullah b. İbrahim. Beyrut: Daru İbn Hazm, 1. Basım, 1996),

Karaoglan, Arslan. "Mâturîdî̀ye Göre Nesih Problematiği". Kahramanmaraş Sütçü İmam Üniversitesi İlahiyat Fakültesi Dergisi, 34 (31 Aralık 2019), 73-111. https://doi.org/10.35209/ksuifd.616976.

Kasımî, Muhammed Cemâlüddîn b. Muhammed Saîd b. Kāsım. Mehasinütt-te'vil. thk. Muhammed Basll. Beyrût: Darü'l-Kütübi'l-illmiyye, 1. Basım, 1418/1997.

Kurtubî, Ebû Abdillâh Muhammed b. Ahmed. el-Câmi li ahkâmi'l-Kur'ân. thk. Ahmed elBerdûnî, İbrahim Atfeș. Kahire: Dâru'l-Kütübi'l-Mısrıyye, 2. Basım, 1964.

Mahallî, Celâleddin \& Süyûtî, Celâleddin. Tefsîrü'l-Celâleyn. Kâhire: Dâru'l- Hadis, ts.

Mâverdî, Ebü'l-Hasen Alî b. Muhammed b. Habîb. en-Nüketü ve'l-uyûn. Beyrût: Dâru Kütübi'lİlmiyye, ts.

Mekkî b. Ebî Tâlib, Ebû Muhammed Hammûş b. Muhammed. Tefsiru'l-hidaye İla buluği'nnihaye. b.y.: Câmiu'ş-Șerîka, 1. Basım, 2008.

Merâgî, Ahmed b. Mustafa. Tefsîru'l-Merâgî. Şerike Mektebe: Matbaatu Mustafa el-Bâbi'lHalebî, 1. Basım, 1946.

Muhāsibī, El-Hāriș. el-Aḳl ve fehmu'l-Ḳur'ân. thk. Huseyn el-Kuvvetli. Beyrût: Dāru'l-Fikr, 1971.

Mukatil b. Süleymân, Ebü'l-Hasen b. Beşîr. Tefsiru Mukatil. thk. Ahmet Ferit. Beyrût: Dâru'l Kütübi'l-İlmiyye, 1. Basım, 2002.

Müslim, Ebü'l-Hüseyn Müslim b. el-Haccâc b. el-Kuşeyrî. Muhtasar sahih-i Müslim. thk. Muhammed Fuad Abdu'l-Bâkî. Beyrût: Dâru İhyâi't-Turâsi'l-Arabî, ts.

Nesâî, Ebû Abdirrahmân Ahmed. es-Sünenü'l-kübrâ. thk. Hasen Abdü'l- Mun'im. Beyrût: Müessesetü'r-Risâle, 1. Basım, 2001.

Nesefî, Ebü'l-Berekât Hâfızüddîn Abdullah b. Ahmed b. Mahmûd. Medârikü't-tenzîl ve hakāảiku't-te'vîl. thk. Yusuf Ali Bedîvî. Beyrût: Dâru'l-Kelimi't-Tayyib, 1. Basım, 1998.

Nizâmüddîn en-Nîsâbûrî, Hasen b. Muhammed b. Hüseyn el-A'rec. Garẩibü'l-Kur'ân ve reġä̉ibü'l-furkān. Beyrût: Dâru Kütübi'l-İlmiyye, 1996.

Râzî, Ebû Abdillâh Fahrüddîn Muhammed b. Ömer b. Hüseyn. Mefâtîhu'l-gayb. Beyrût: Dâru İhyâi't-Türasi'l-Arabî, 2. Basım, 1420/1999.

Reşîd Rizâ, Muhammed. Tefsiru'l-menar (Tefsîru'l-Kur'âni'l-hakîm). el-Heyetü'l-Mısriyyetü'lAmme, 1990.

Sa'lebî, Ebû İshâk Ahmed b. Muhammed b. İbrâhîm. el-Keșf ve'l-beyân an tefsîri'l-Kưr'ân. thk. İbn Aşûr. Beyrût: Dâru İhyâi't-Türasi'l-Arabî, 1. Basım, 2002.

San'ânî, Ebû Bekr Abdürrezzâk b. Hemmâm b. Nâfî. Tefsîrü'l-Kururân. thk. Mustafa Müslim Muhammed. Riyad: Mektebetü'r-Rüşd, 1. Basım, 1989.

Seâlebî, Ebû Abdirrahman b. Muhammed. el-Cevâhiri'l-Hisan fí Tefsîri'l-Kur'ân. thk. Muhammed Ali Muavvid. Beyrût: Dâru İhyâi't-Türasi'l-Arabî, 1997.

Seyyid b. Kutub, b. İbrâhîm b. Hüseyn. fi Żlâli'l-Kurưân. Beyrût: Dâru'ş-Şurûk, 1412/1992. 
Sindî, Ebü'l-Hasen Nûruddîn Muhammed b. Abdilhâdî. Haşiyetü's- Sindî alâ Müsnedi'l-Imâm Aḥmed b. Hanbel, thk. Ebû Muaz Târık, Riyad: Dâru'l- Me'sûr li'n-Neşr ve't-Tevzi', $1431 / 2010$.

Subhi Sâlih, b. İbrahim . Mebâhis fî ulûmi'l- Kur'ân. Beyrût: Dâru'l-İlim li'l-Melâyin, 2005.

Süyûtî, Ebü'l-Fazl Celâlüddîn Abdurrahmân b. Ebî Bekr. Lübâbu'n-nukûl fî esbâbi'n-nüzûl. thk. Ahmed Abdü'ş-Şâfî. Beyrût: Dâru'l Kütübi'l-İlmiyye, ts.

Süyûtî. ed-Dürru'l-mensûr. Beyrût, ts.

Süyûtî. el-İtkân fî ulûmi'l- Kur'ân. thk. Mustafa el-Buga. Beyrût: Dâru İbn Kesîr, 1987.

Şâzelî, Ebü'l-Abbâs Ahmed b. Muhammed b. Mehdî el-Hasenî. el-Bahrü'l-medîd fî tefsîri'lKur'âni'l-mecîd. thk. Ahmed Abdullah el-Kureşî. Doktor Hasan Abbas Zeki, $1419 / 1998$.

Şevkânî, Ebû Abdillâh Muhammed b. Alî b. Muhammed es-San'ânî el-Yemenî). Fethu'l-kadîr. Beyrût: Dâru İbn Kesîr, 1. Basım, 1414/1994.

Şinkīî̂, Muhammed el-Emîn b. Muhammed el-Muhtâr b. Abdilkādir. Edvâü'l-beyân fî izâhi'lKur'ân bi'l-Kur'ân. Beyrût: Darü’l-Fikr, 1995.

Taberânî, Ebü'l-Kāsım Süleymân b. Ahmed. el-Mu'cemü'l-kebîr. thk. Hamdî bin Abdülmecid Selefi. Kahire: Mektebetü İbn Teymiyye, 2. Basım, 1994.

Taberî, Ebû Ca'fer Muhammed b. Cerîr b. Yezîd. Camiu'l-beyan fí te'vîlli'l-Kur'an. thk. Abdullah b. Abdülmuhsin et-Türkî. Dâru Hicr, 1. Basım, 2001.

Tirmizî, Ebû Îsâ Muhammed b. Îsâ. Sünenü't-Tirmizî (el-Câmi'u'l-kebîr). thk. Beşşar Avvad Ma'ruf. Beyrût: Dârü'l-Garbi'l-İslâmî, 1998.

Vâhidî, Ebü'l-Hasen Alî b. Ahmed b. Muhammed b. Ali. Esbâbü nüzûli'l-Kur'ân. thk. Usâm b. Abdilmuhsin el-Humeydan. ed-Demmâm: Dâru'l-Islâh, 2. Basım, 1992.

Zemahşerî, Ebü'l-Kâsım Mahmûd b. Ömer b. Muhammed. el-Keşşâfan hakâikı ğavâmizi't-tenzîl. Beyrût: Dâru'l-Kitabi'l-Arabî, 1407/1987.

Zerkeşî, Bedrüddîn Muhammed Abdullah. el-Burhân fî ulûmi'l- Kur'ân. thk. Muhammed Ebu'lAzl İbrahim. Beyrût: Darü'l- Ma'rife, 1. Basım, 1391/1971.

Zürkânî, Muhammed Abdü'l-Azîm. Menâhilü'l-irfân fì ulûmi'l- Kur'ân. Dâru İhyâi Kütübi'lArabî, ts. 